Article

\title{
Sediment Supply and Hydrogeological Hazard in the Quebrada de Humahuaca (Province of Jujuy, Northwestern Argentina)-Rio Huasamayo and Tilcara Area
}

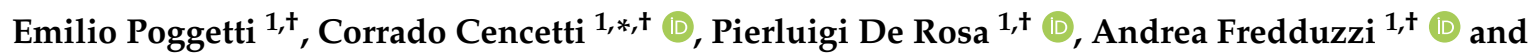 \\ Felipe Raphael Rivelli ${ }^{2}$ \\ 1 Department of Physics and Geology, University of Perugia, 06125 Perugia, Italy; \\ emilio.poggetti@gmail.com (E.P.); pierluigi.derosa@unipg.it (P.D.R.); andrea.fredduzzi@unipg.it (A.F.); \\ 2 Ex Escuela de Geologia, Universidad Nacional de Salta, A4400 Salta, Argentina; feliperivelli@gmail.com \\ * Correspondence: corrado.cencetti@unipg.it; Tel.: +39-075-585-0303 \\ + Current address: Viale Zefferino Faina 4, 06125 Perugia, Italy.
}

Received: 30 October 2019; Accepted: 11 November 2019; Published: 16 November 2019

\begin{abstract}
This paper describes the hydrogeological hazard in a reach of Quebrada de Humahuaca, (Upper Valley of Rio Grande de Jujuy, in the Argentine Andes), elected a World Heritage Site by UNESCO in 2003. Along the Quebrada, the Rio Huasamayo, flowing into the Rio Grande, formed a large alluvial fan where the village of Tilcara was built. The final reach of Rio Huasamayo is an artificial channel, embanked by unconsolidated material removed from the riverbed. The village is located in an area at a lower elevation with respect to the riverbed, still in aggradation; so it is affected by an evident hydrogeological hazard. The main cause of the riverbed aggradation is the enormous sediment supply from the slopes of the Rio Huasamayo basin. The aim of the paper is to estimate the soil loss on the slopes and the consequent sediment supply to the main stream, identifying the areas of the basin mostly affected by erosion processes that cause the aggradation of the Rio Huasamayo riverbed. In this case, due to the lack of hydrometeorological stations (monitoring rainfalls, temperature, flow rates, etc.), soil loss and sediment supply to the main stream cannot be estimated through the application of commonly used models in the literature (e.g., USLE, RUSLE, USPED). Here the Gavrilovic method (EPM) was applied in combination with the data of the CORINE Project, allowing the estimation of the volume of material exiting from the catchment. So the main supplying areas (sub-basins of the Rio Huasamayo) can be identified where focused interventions for the control of solid transport could be realized, to mitigate the process of riverbed aggradation.
\end{abstract}

Keywords: Argentine Andes; hydrogeological hazard; sediment supply; CORINE method; EPM method

\section{Introduction}

The study of the sediment yield/supply from the slopes is very important because it has implications for flood hazard-if the volume of sediment exceeds the stream power, the aggradation of the riverbed and the raising of the free surface of the water occur. The process can lead to the overcoming of the river banks/leeves and to the flooding of the alluvial plain [1,2]. The correlation between morphological changes in riverbeds, processes of aggradation or degradation and consequent changes in water levels is widely debated and demonstrated, particularly for events with a high return period [3-5]. The above mentioned authors suggest that in hydraulic risk modelling to support landscape planning, solid transport and the consequent morphological variations of the riverbed 
should also be considered. While in lowland areas it is possible that floods are mainly determined by flow discharges - especially for flows with low return period-in mountain environments (small basins with steep slopes) floods are practically always related to strong sedimentary inputs due to landslides and debris flows [6-8]. Therefore, a detailed knowledge of sediment production (both in terms of supplying areas and in quantitative terms) is important to correctly define the conditions of hydrogeological hazard and risk in mountain environments.

The paper examines a case study - the village of Tilcara, located in the median valley of the Quebrada de Humahuaca (nothwestern Argentina) on the left bank of the Rio Grande, above the large alluvial fan of the Rio Huasamayo, a tributary of the Rio Grande itself (Figure 1A). The final reach of this stream has a superelevated riverbed, forced by artificial banks (Figure 1B) to flow at higher altitudes than the residential area. This represents a situation of high risk of flooding, as already happened also in the recent past [9]. Under these conditions, the assessment of the production of sediment within the Rio Huasamayo basin is necessary for the analysis of the causes that have led to the aggradation of the riverbed and therefore to the current conditions of hydrogeological hazard.
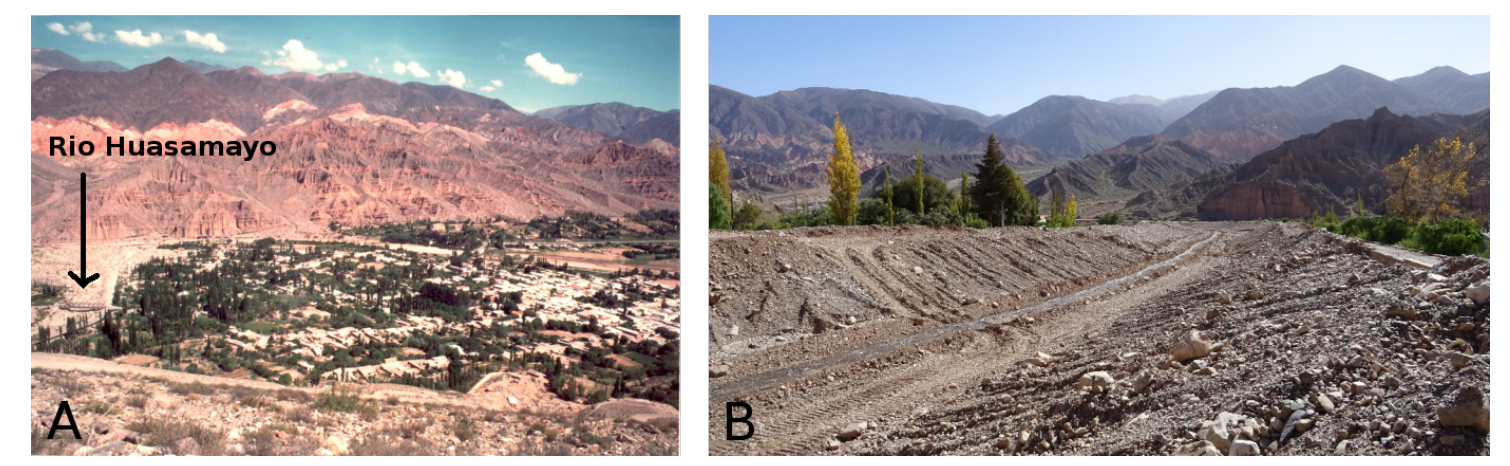

Figure 1. In the photo (A) you can see the alluvial fan of the Rio Huasamayo (the point of view is close to the apex), where the village of Tilcara is located. In the same photo (A) the riverbed is visible, clearly elevated with respect to the inhabited center. The photo $(\mathbf{B})$ represents a detail of the final stretch of the Rio Huasamayo, close to the confluence with the Rio Grande, forced between artificial levees that, however, do not guarantee sufficient safety conditions for the village of Tilcara.

To this aim, two methods were used in combination-the Gavrilovic method (Erosion Potential Method (EPM)) and the CORINE method.

Gavrilovic's model [10] was originally developed and applied on small basins, with torrential riverbeds; it was later modified, first by Zemljic [11] and later by Djorovic and Gravilovic [12]. The last version of the model, applied here, is the one proposed by Gavrilović [13] in 1988. Several authors have applied the method, especially in non-instrumented basins in the Mediterranean area [2,14-22]. Nevertheless, a comparison with the PSIAC method $[23,24]$ showed the same pattern for the predicted sediment yield, with a correlation coefficient of 0.95 ; it confirms the applicability of the EPM method for semi-arid and arid catchments $[25,26]$. Even the dimensions of the basins studied by these authors are comparable with the analyzed here.

The CORINE method Commission of European Community [27] allows to identify from a qualitative point of view, the spatial distribution of areas characterized by intense erosion, by obtaining two indexes-PSER (Potential Soli Erosion Risk) and ASER (Actual Soil Erosion Risk—see Methods Section for detail).

The application of the two methods allowed the identification of the main areas of sediment supply and the assessment of the produced sediments. The results were used to define the priorities, types and areas of intervention, at basin level, for the mitigation of the aggradation process in the riverbed. 


\section{Material (The Study Area): The Quebrada De Humahuaca and the Basin of the Rio Huasamayo}

The basin of the Quebrada de Humahuaca, that is, Upper Valley of Rio Grande de Jujuy (Rio San Francisco basin, northwestern Argentina) extends in N-S direction in an area of $6615 \mathrm{~km}^{2}$ and is elongated in the same direction of the main geological structures of the Cordillera Oriental of Andes. The difference in altitude is about $4600 \mathrm{~m}$, from Cerro Chani (5896 m a.s.l.), located in the southern part of the basin, until Dique Los Molinos, close to San Salvador de Jujuy, at $1298 \mathrm{~m}$ a.s.l. The riverbed, of braided type, is entrenched in a narrow valley extended from the boundary of Bolivia (Tres Cruces) until San Salvador de Jujuy, with an average gradient of 1.4\% (see Figure 2).
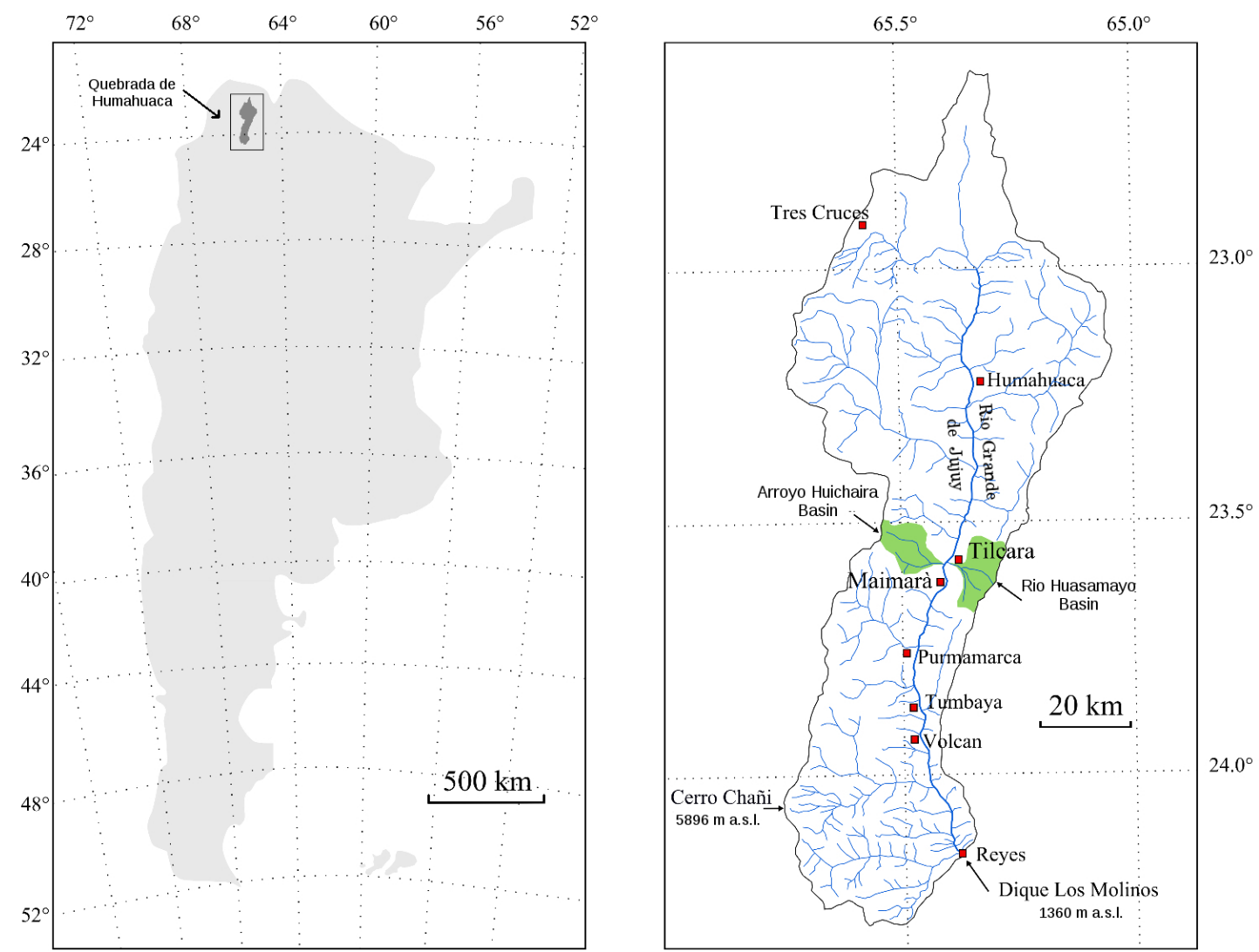

Figure 2. Location of the Quebrada de Humahuaca (Upper Valley of Rio Grande de Jujuy, northwestern Argentina).

The main morphogenetic process affecting the Quebrada de Humahuaca is the physical weathering which, associated with a strong fracturing of the outcropping rocks, produces an intense erosion of the slopes [28], generating great volumes of unconsolidated material. The concentrated runoff, the gravitational processes and the mass removal (due to frequent and widespread debris flows) cause the over-flooding of the valley floors and the riverbeds aggradation. The consequence of this systematic aggradation is the generation of superelevated riverbeds which, during the rainy season, increase the flooding hazard of the areas close to the streams.

The Quebrada de Humahuaca was elected World Heritage Site by UNESCO in 2003. Therefore, the tourist flow has increased since that date. However, most of the Quebrada is subject to hydrogeological hazard mainly caused by the mobilization of material from the slopes through debris flow processes and by the conspicuous sediments supply from the side tributaries that often cause flooding of the main valley. For example, the Ferrocarril G.ral Belgrano, the only rail link between Argentina and Bolivia, has long since been abandoned due to the frequent flooding that imply high maintenance costs. 


\subsection{Climatic Characteristics}

There are not many meteorological stations in northwestern Argentina and this is a big problem for the hydrogeological monitoring. During the period 1934-1990, in the whole Quebrada de Humahuaca, they were 18; to date, they are less than a dozen and each of them is managed by different Bodies. The data often have no continuity and are difficult to correlate with each other.

Based on the available data, the climate of the Quebrada de Humahuaca appears to be of an arid continental type, with scarce but intense rainfall in the summer season and with very dry winters. Average temperatures are between $-5{ }^{\circ} \mathrm{C}$ and $+5^{\circ} \mathrm{C}$ in winter, reaching a maximum of $25^{\circ} \mathrm{C}$ up to $30^{\circ} \mathrm{C}$ in summer. Average annual rainfalls fluctuates around $300 \mathrm{~mm} / \mathrm{yr}$, concentrated in the austral summer months (December-March). The rainfall gauge that records the minimum rainfalls is Maimarà, located just south of Tilcara ( $119 \mathrm{~mm} / \mathrm{yr}$ ). To the south this value increases rapidly, so much so that in Termas de Reyes (1800 m a.s.l.), located at the southern portion of the Quebrada de Humahuaca, values of just over $1500 \mathrm{~mm} / \mathrm{yr}$ are recorded.

Chayle and Aguero [29] distinguish two zones, inside the Quebrada, clearly different from the climatic and vegetational point of view, located respectively at $\mathrm{N}$ and $\mathrm{S}$ of Tilcara-(1) the northern one, characterized by a marked absence of vegetation (excluding some xerophilous species, more widespread near Tilcara), with scarce rainfalls and high daily temperature range; (2) the southern one, with higher values of rainfalls, lower daily thermal excursion and with more abundant vegetation, which can reach the characteristics of a humid tropical climate in the sector close to San Salvador de Jujuy.

The average annual temperature in Tilcara is $13^{\circ} \mathrm{C}$, with a maximum of $17.1^{\circ} \mathrm{C}$ in January and a minimum of $7.1^{\circ} \mathrm{C}$ in July [30]. However, the daily thermal excursion is very high. Braun Wilke [31] determined a temperature gradient for the whole Quebrada which decreases approximately $0.55{ }^{\circ} \mathrm{C}$ every $100 \mathrm{~m}$ of altitude. The rainfalls regime recorded in the Tilcara gauge (Figure 3), recorded in the period 1934-1990, shows a dry winter and a rainy summer. The average annual precipitation is $136 \mathrm{~mm}$, as a consequence of the orographic precipitations that are generated with the arrival of the Atlantic anticyclone.

The precipitations regime, with rainfalls concentrated in the summer periods and characterized by intense meteoric events, is the predisposing element to the occurrence of degradation phenomena on the slopes, bare of vegetation, triggering debris flows [28].

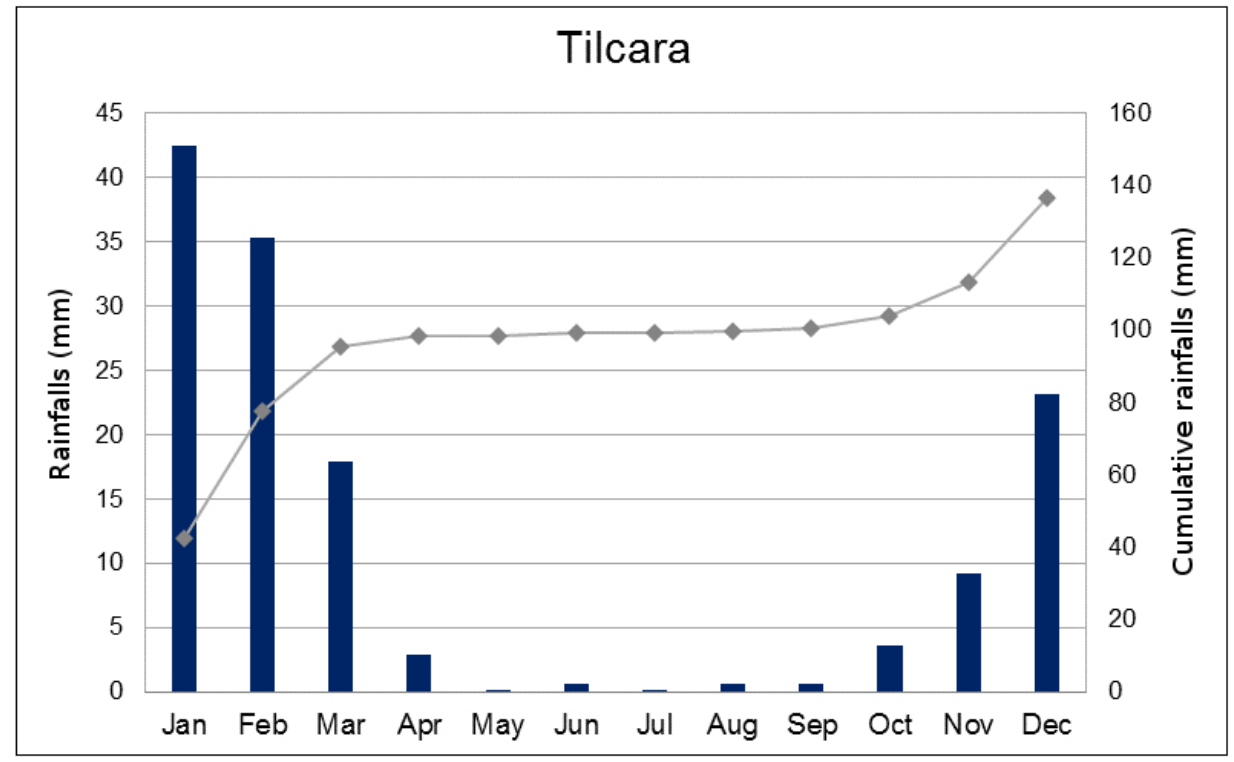

Figure 3. Monthly rainfalls in the period 1934-1990, registered by the Tilcara rain gauge. 


\subsection{General Geological Characteristics}

In the Quebrada de Humahuaca basin, large outcrops of Precambric and Lower Paleozoic formations prevail, while the formations of the Upper Paleozoic (from Silurian onwards) are practically absent. A stratigraphic gap extends from the Paleozoic to the Lower Cretaceous. However, Tertiary sediments are also present in scarce and fragmented outcrops [32].

It should be highlighted, instead, the abundant presence of Pliocene and Quaternary clastic sediments that mainly occupy the central area of the valley, just around Tilcara, often affected by tectonic phases (Solis, 1993-Figure 4). Telescopic fans mark the different uplift phases and the consequent fluvial re-incision of the sediments themselves (Figure 5).

The most ancient outcropping formation is the Formación Puncoviscana, of Precambrian age [33-36]; it is a very thick formation, about $1500 \mathrm{~m}$, weakly metamorphosed and made up of shales, phyllites, greywackes and quartzites. Conglomerates and sandstones of continental environment, in river facies, belonging to the Units of the Grupo Mesón of the Cambrian [33] and conglomerates, sandstones and clays in continental shelf facies, belonging to the Units of the Grupo Santa Victoria of the Ordovician [33,37-39] overlap with angular unconformity.

There are few outcrops of formations referable to the Upper Paleozoic; the outcrops of the Mesozoic formations should instead be highlighted. The oldest are magmatic rocks from the Lower-among these, particular mention should be made of the Formación Aguilar, a granitic pluton, very important from an economic point of view for its $\mathrm{Pb}$ and $\mathrm{Zn}$ mineralizations [40-45], still object of mining cultivation (Mina Aguilar, at W of Humahuaca).

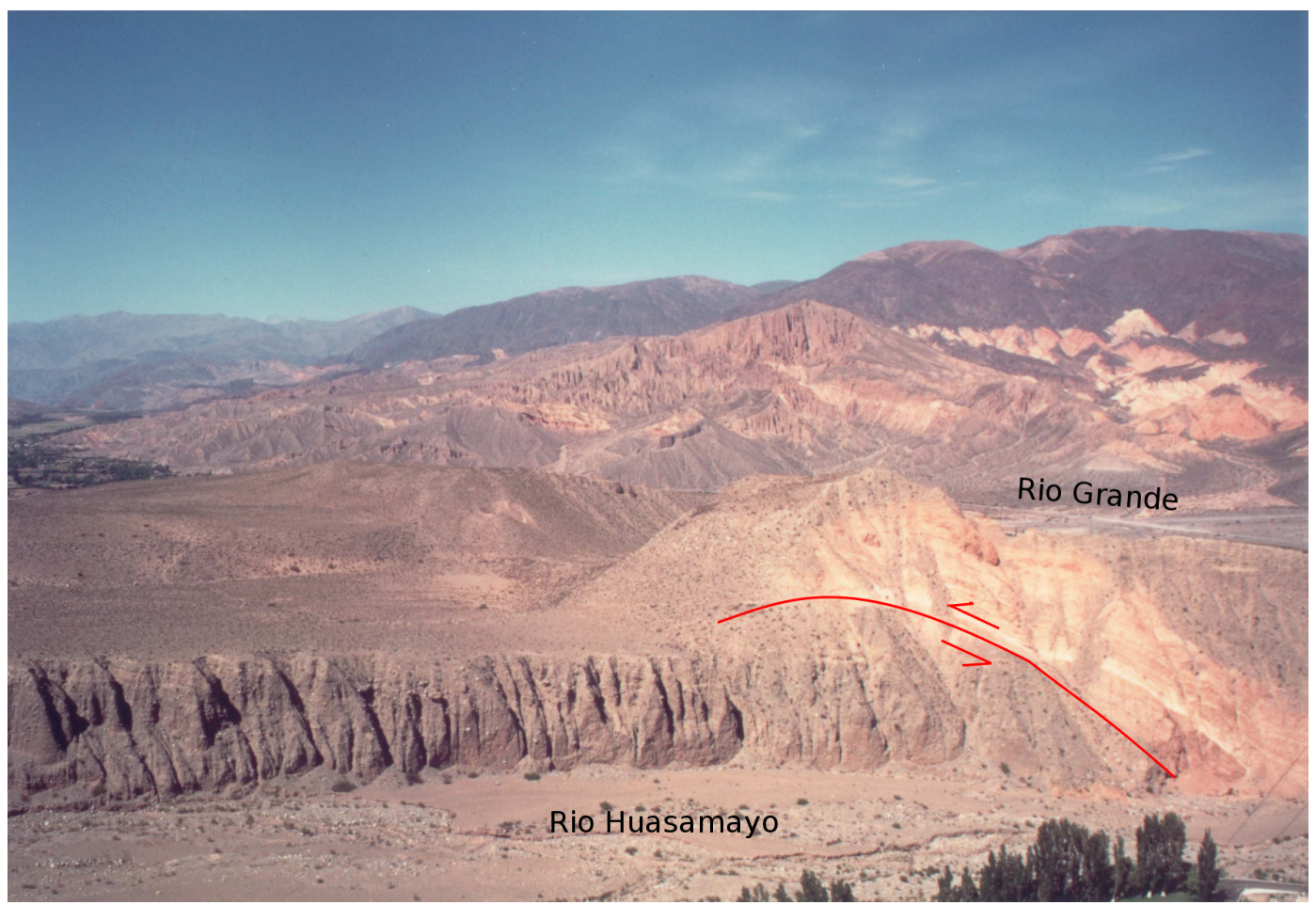

Figure 4. Reverse fault close to Tilcara, with Tertiary sediments of Formación Maimará overlapping clastic Quaternary alluvial sediments. In the middle distance the Rio Grande valley is visible. 


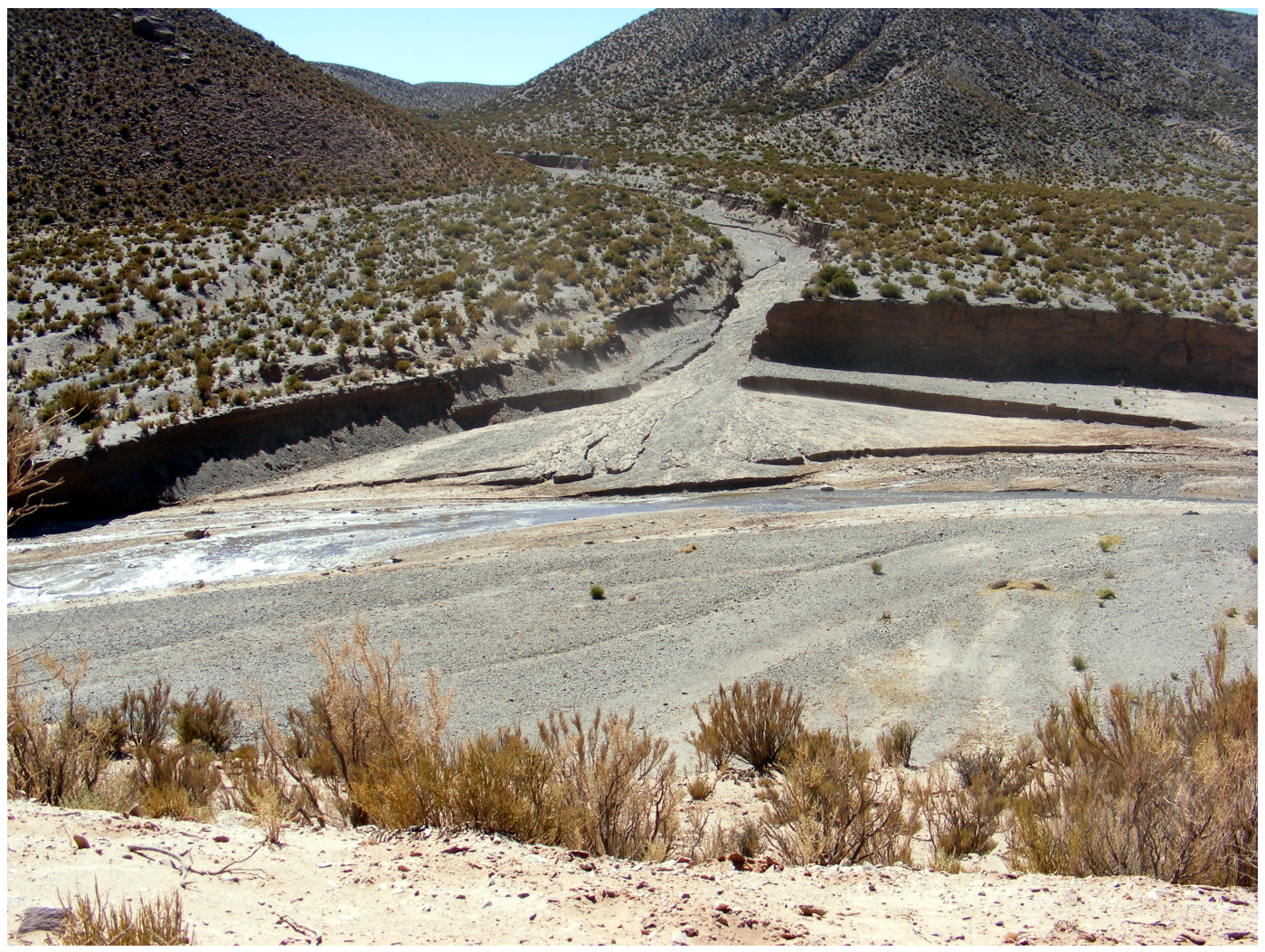

Figure 5. Telescopic fans along the Quebrada de Humahuaca.

The Mesozoic-Tertiary sedimentary cycle (Cretaceous-Paleogene) is represented by Grupo Salta [46,47], subdivided into the subgroups Pirgua, Balbuena and S.ta Barbara [48-50]. The formations of the Grupo Salta are almost entirely in continental facies and constitute the deposits of an intracratonic rifting phase [51] to which the placement of the already named Aguilar granites is connected in the study area. The overlapping formations, Formación Casagrande (Middle Eocene) [52-54] and Formación Río Grande (Miocene) [55], show the same depositional environment and consist of conglomerates and sandstones in fluvial facies (braided type), with clayey levels, which are rarer upwards. The following formations are also found in continental facies-the Formación Maimará [56] which covers the central sector of the Quebrada, consisting of sandstones and conglomerates with clayey matrix; referable to ancient syntectonic alluvial fans raised with respect to the current thalweg of the Rio Grande; and in heteropia of facies towards the north-west, the Formación Uquia [57], consisting of yellow sands with intercalated conglomerates in more frankly fluvial facies (braided). The sediments of the ancient alluvial fans of Quaternary age are the product of the recent morphological evolution of the Quebrada and they are in great quantity inside the depression of Humahuaca. They consist of gravels that also incorporate large boulders with a stratified structure and levels of volcanic scoriae.

The Formacion Purmamarca of the Pleistocene age [32,58], on the other hand, has more morphological than chronostratigraphic significance; although it is made of the same material of alluvial formations as already described, it represents a morphological reference level of local importance and it is especially present in the Quebrada de Purmamarca, from which it takes its name. The gravels and the embedded boulders of phyllites and tillites come mainly from the Formación Puncoviscana which outcrops in the neighboring areas. Its structures and the poor sorting make it possible to refer to deposits produced by debris flows processes and, secondarily, by fluvial processes, connected to the Pleistocene periglacial climatic conditions. The dune fields refer instead to accumulations of aeolian processes affecting the Puna, west of the Quebrada. These are aeolian sands that constitute alignments of longitudinal dunes and barchans. Finally, all the more recent deposits, from the Pleistocene to the Holocene, of predominantly fluvial origin (gravels, sands, the last 
generation of alluvial fans, more recent terraced sediments of the Quebrada) are identified with the term "Undifferentiated Quaternary".

Figure 6 (from Cencetti [28]) shows a medium-scale geological map of the central portion of the Quebrada de Humahuaca, more specifically the subject of this note.

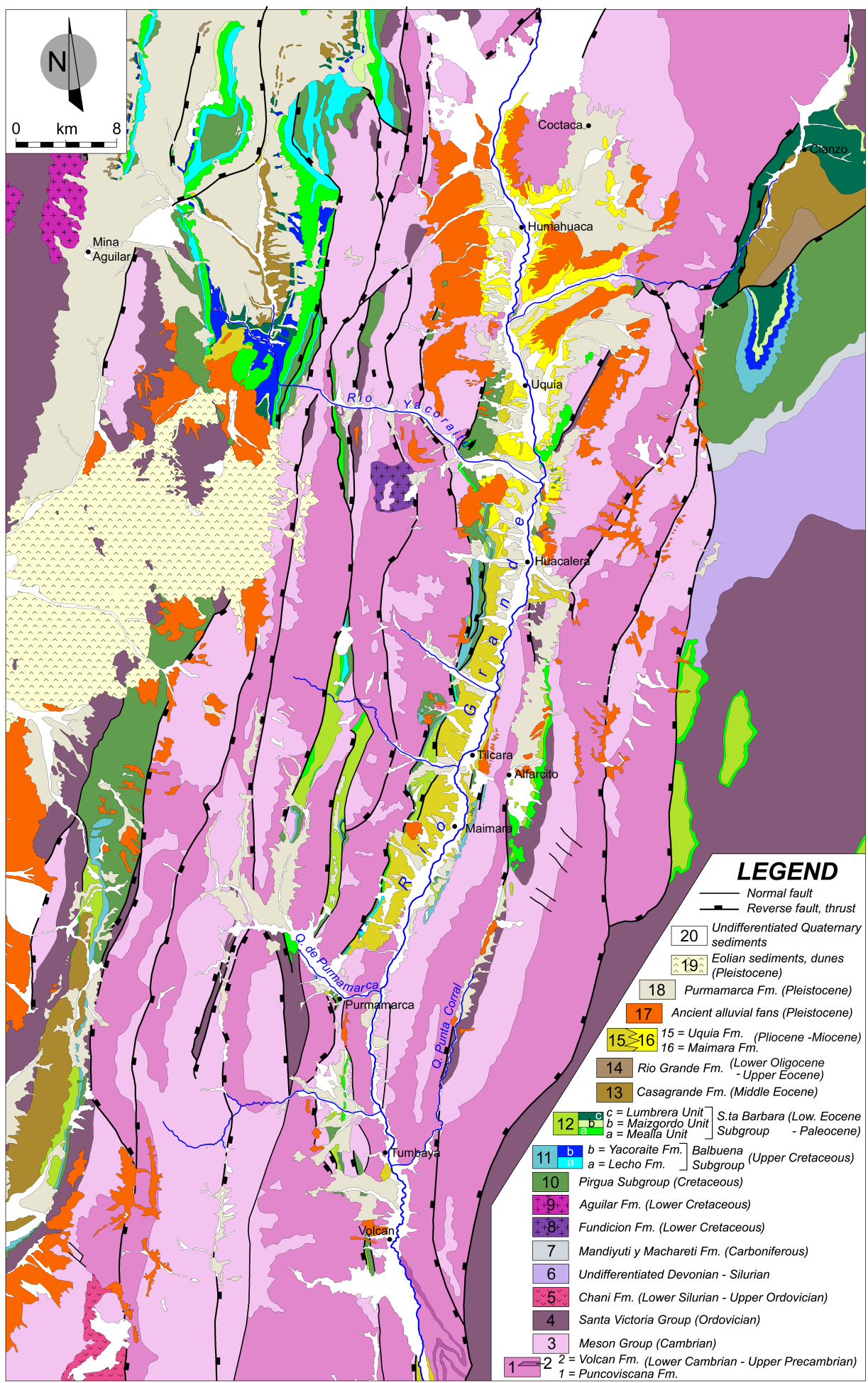

Figure 6. Geological map of the middle valley of the Quebrada de Humahuaca (redrawn and modified from SEGEMAR [32] in Cencetti) [28]. 


\subsection{The Rio Huasamayo}

The village of Tilcara is located close to the confluence between the Rio Grande and two tributaries (Figure 7), respectively the Rio Huichaira on the right bank, and the Rio Huasamayo on the hydrographic left. The Rio Huasamayo, subject of this note, originates from the confluence of five streams and reaches the Rio Grande (Quebrada de Humahuaca) at $2450 \mathrm{~m}$ a.s.l., with a length of just $4 \mathrm{~km}$ and with a very high average gradient $(12 \%)$. Its watershed has an area of about $114 \mathrm{~km}^{2}$; its tributaries originate between Ovejería and Suncho Grande mountains, at altitudes between 4600 and $4850 \mathrm{~m}$ a.s.l., and flow along slopes characterized by high steepness, into a gorge (Garganta del Diablo).

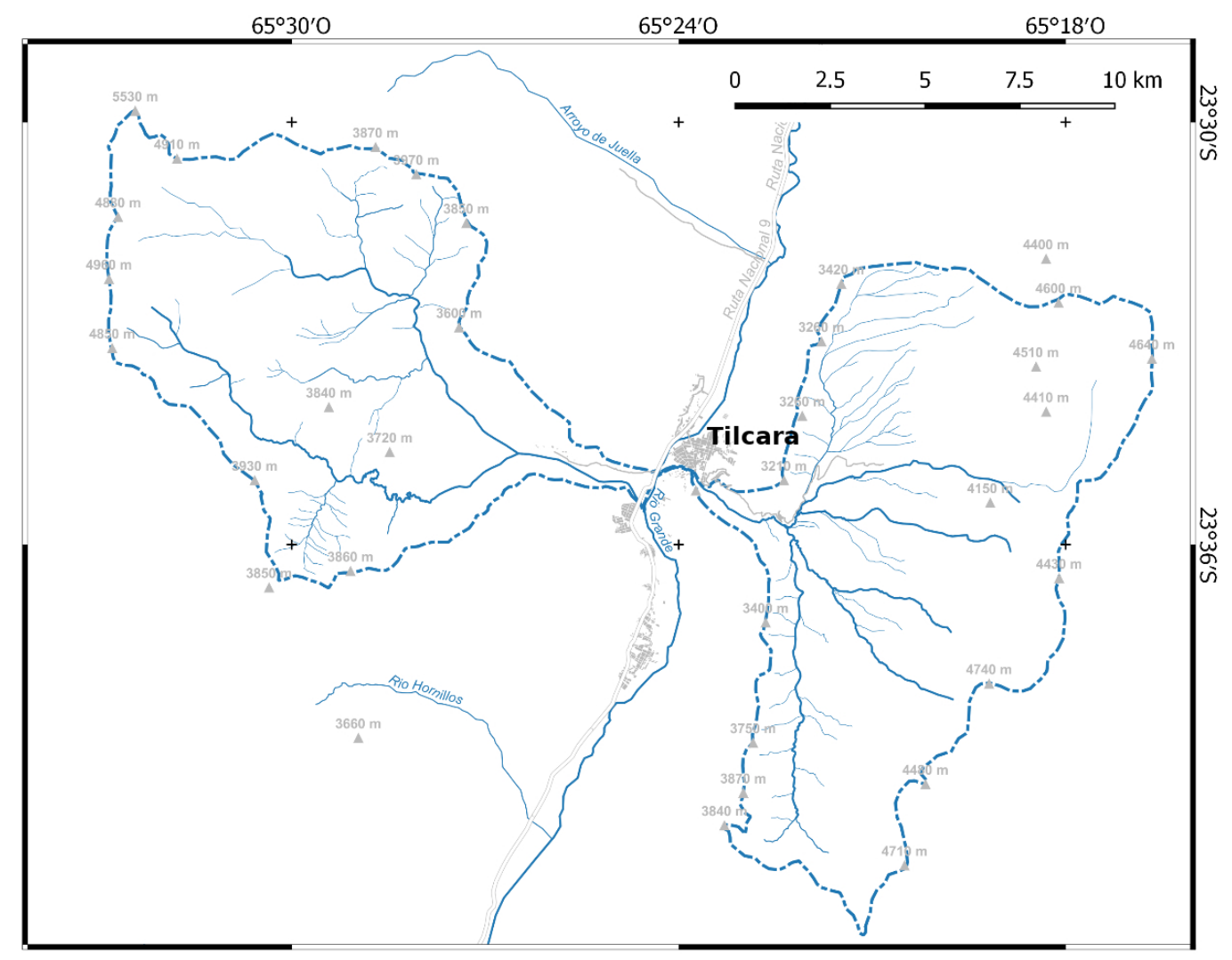

Figure 7. The area of Tilcara, near the confluence between the Rio Grande and two of its tributaries: the Rio Huichaira (at W, in the right hydrographic) and the Rio Huasamayo (at E, in the hydrographic left), whose respective basins are delimited.

The Rio Huasamayo, starting from about 95,000 years, built an alluvial fan extending for about $5 \mathrm{~km}^{2}$ [59] where the town of Tilcara is located. It is a mixed-type alluvial fan, formed both by the systematic aggradation of material brought by the stream and by gravitational processes such as debris flows $[9,59]$.

Actually, the Rio Huasamayo is forced to flow into a narrow fan sector within an artificial bed. This condition and the continuous aggradation have led to an increase in altitude of its thalweg, which is located at a higher altitude than the inhabited area of the village of Tilcara. This situation represents a clear risk of flooding for the town. Rivelli and Zelarayan [9] have carried out a census, based on historical data, of the floods caused by the Rio Huasamayo, identifying over twenty catastrophic events from 1867 (the first documented) to 2016. The same authors have carried out a hazard analysis, through a zoning of the Tilcara alluvial fan, identifying the areas that have been most affected in the past (and therefore may be in the future) by the Rio Huasamayo floods.

To solve the problem, Marcato et al. [60] proposed the deviation of the Rio Huasamayo before the village, building an artificial channel working as drainage channel. The preservation of Tilcara, however, 
would not reduce the hydraulic risk, which would only be transferred downstream the Quebrada towards the village of Maimará. Then, we propose an alternative solution, intervening at the origin of the problem. By way of direct observations and the study of existing maps and satellite images, by applying the method proposed by Gavrilovic and using the CORINE Project data, it is possible to estimate the volume of material produced by the Rio Huasamayo watershed, identifying the main supplying areas where focused interventions for the control of solid transport could be realized [9].

\section{Methods}

In the literature there are several formulations and quantitative models that allow assessment of soil erosion, that is, USLE-Universal Soil Loss Equation (i.e., References [61-63]; RUSLE-Revised USLE [64-66]; USPED—Unit Stream Power-based Erosion Deposition [67]. They differ in the input data and in the processing and accuracy of the results. Nevertheless, they are not usable due to the lack of necessary input data such as specific data about rainfalls.

So, in order to estimate soil erosion in the Rio Huasamayo catchment area, the following methods have been used:

- CORINE (COoRdination of INformation on the Environment) method [27], of qualitative type, useful for identifying the distribution of areas characterized by intense erosion;

- EPM (Erosion Potential Method) proposed by Gavrilovic [10], of quantitative type, capable of evaluating the average production of sediments in a watershed. This model is based on empirical formulas that allow us to obtain the volume value of sediment production. It takes into consideration some geomorphological, climatic, lithological and vegetation parameters and allows a theoretical estimate of the volume of material produced by erosion in a river basin. The model uses a reduction coefficient, to consider that not all the produced material reaches the closing section of the hydrographic basin due to redeposition processes. Then the amount of debris carried by the stream through closing section is determined.

\subsection{Application of the CORINE Method}

The CORINE method allows to obtain two indexes:

- PSER (Potential Soil Erosion Risk) which indicates the susceptibility of soils to erosion, considering the factors linked to land use, climatic and topographic conditions;

- ASER (Actual Soil Erosion Risk) which indicates erosion under current conditions of land use and vegetation cover.

The estimation of erosion according to this method develops through two main phases (Figure 8). In a first step the PSER index is calculated, by adding the Soil Erosion Index (SEI), the Erosivity Index (EI, due to climate conditions), and the topographyc Slope Index (SI, due to the incline of the slope), by determining values that correspond to different classes. With this operation we obtain a value of soil susceptibility to erosion, just called Potential Soil Erosion Risk (PSER).

In particular, the Soil Erosion Index (SEI) is evaluated considering the texture of soil, its depth (i.e., its thickness, interpreted as the distance between the surface and the upper part of the bedrock or of the original unaltered material, divided into 3 classes: $>750 \mathrm{~mm} ; 250-750 \mathrm{~mm} ;<250 \mathrm{~mm}$ ), and the superficial stoniness, that is, the greater or lesser presence of unconsolidated material of coarse grain size ( $>20 \mathrm{~mm}$ of average diameter), divided into 2 classes-completely protected soil (percentage of coverage $\%>10$ ); not protected soil (percentage of coverage $\%<10$ ). The grain-size characteristics of the soil allow to define three granulometric classes (Figure 9; Table 1) obtained on values proposed by the United States Department of Agriculture (USDA [68]). 


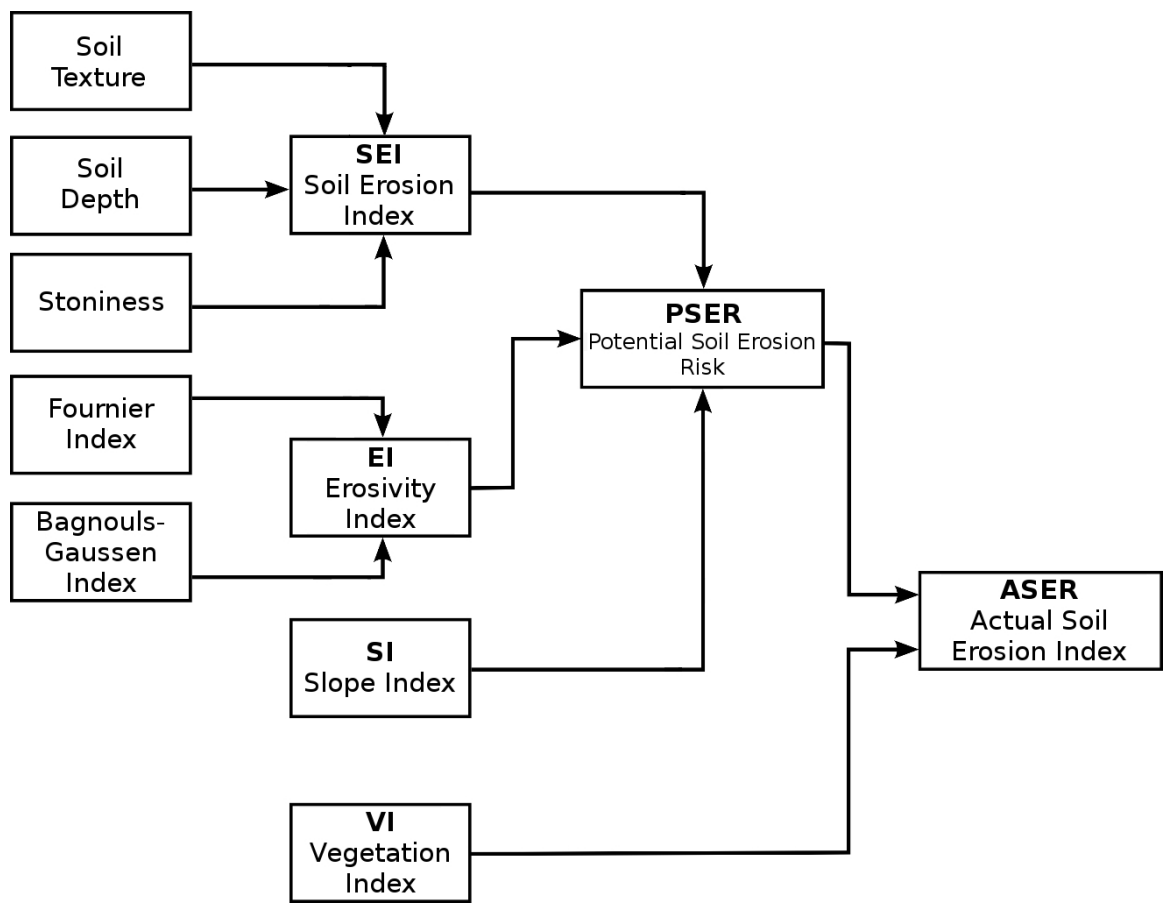

Figure 8. Flow diagram of CORINE method.

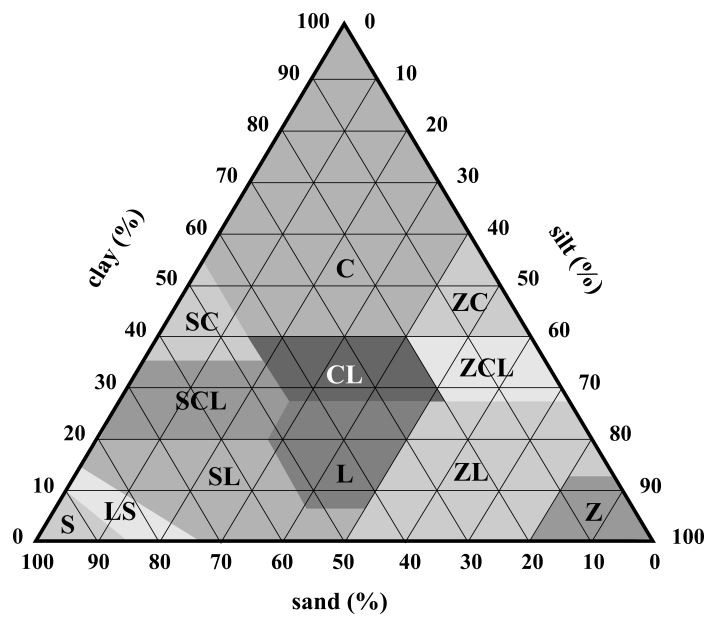

Figure 9. Textural Classification Chart (by USDA [68], redrawned). C: clay; SC: sandy clay; ZC; silty clay; SCL: sandy clay loam; CL: clay loam; ZCL: silty clay loam; S: sand; LS: loamy sand; SL: sandy loam; L: loam; ZL: silt loam, Z: silt.

Table 1. Grain-size classes defined by the texture of soil.

\begin{tabular}{cll}
\hline Class & Description & Texture \\
\hline 1 & Low erodible & C, SC, ZC \\
2 & Moderate erodible & SCL, CL, ZCL, LS, S \\
3 & Highly erodible & L, ZL, Z, SL \\
\hline
\end{tabular}

The value of Soil Erosion Index (SEI) is obtained from the product:

$$
\text { SEI }=\text { soil texture } * \text { soil depth } * \text { stoniness }
$$

and based on the result, the index value is assigned as shown in Table 2. 
Table 2. Soil Erosion Index (SEI).

\begin{tabular}{cll}
\hline Index & Description & Range \\
\hline 1 & Low & $0-3$ \\
2 & Middle & $3-6$ \\
3 & High & $>6$ \\
\hline
\end{tabular}

The Erosivity Index (EI) is obtained starting from the Fournier-Arnoldus index (FI: Fournier Index, Arnoldus, [69]) and from the aridity index of Bagnouls-Gaussen (BGI, Gaussen, [70,71]). The Fournier index, modified by Arnoldus, is obtained from the expression:

$$
F I=\sum_{i=1}^{12} \frac{p_{i}^{2}}{P}
$$

where:

$i=$ month $i_{t h}$;

$p_{i}=$ average monthly rainfalls $(\mathrm{mm}) ;$

$P=$ average annual rainfalls $(\mathrm{mm})$.

The value of FI is assigned as in Table 3.

Table 3. Fournier Index (FI) classes.

\begin{tabular}{cll}
\hline Index & Description & Range \\
\hline 1 & Very low & $<60$ \\
2 & Low & $60-90$ \\
3 & Middle & $90-120$ \\
4 & High & $120-160$ \\
5 & Very high & $>160$ \\
\hline
\end{tabular}

Bagnouls-Gaussen's aridity index (BGI) is calculated on the basis of the monthly moisture balance, estimating the evapotranspiration starting from the temperature. It is obtained by applying the equation:

$$
B G I=\sum_{i=1}^{12}\left(2 t_{i}-p_{i}\right) \cdot k_{i}
$$

where:

$i=$ month $i$ th;

$t_{i}=$ average monthly temperature $\left({ }^{\circ} \mathrm{C}\right)$;

$p_{i}=$ average monthly rainfalls $(\mathrm{mm})$;

$k_{i}=$ proportion of month $i_{t h s}(i)$, where $2 t_{i}-p_{i}>0$ (obtained by linear interpolation).

To estimate the value of BGI, it is necessary to calculate by linear interpolation the dates in which the period begins or ends where $2 t i>p i$. For this reason, it is assumed that the temperature and precipitation values are produced on the fifteenth day of the month. The value of BGI is then assigned as in Table 4.

Table 4. Bagnouls-Gaussen's aridity index (BGI) classes.

\begin{tabular}{cll}
\hline Index & Description & Range \\
\hline 1 & Wet & 0 \\
2 & Moderately wet & $0-50$ \\
3 & Arid & $50-130$ \\
4 & Very arid & $>130$ \\
\hline
\end{tabular}


The value of the climatic Erosivity Index (EI) is then obtained from the product:

$$
E I=F I \cdot B G I
$$

assigning to EI class the value as in Table 5.

Table 5. Erosivity Index (EI) classes.

\begin{tabular}{cll}
\hline Index & Description & Range \\
\hline 1 & Low & $<4$ \\
2 & Middle & $4-8$ \\
3 & High & $>8$ \\
\hline
\end{tabular}

The Slope Index (SI) is established starting from topographical characteristics, dividing the territory into square cells $\left(1 \mathrm{~km}^{2}\right)$, in which the average value of the slope is calculated. The SI is assigned to this slope according to the range of values as in Table 6.

Table 6. Slope Index (SI) classes.

\begin{tabular}{cll}
\hline Class & Description & Range (\%) \\
\hline 1 & Flat or slightly slope & $<5$ \\
2 & Moderate & $5-15$ \\
3 & Accentuate & $15-30$ \\
4 & Very accentuate & $>30$ \\
\hline
\end{tabular}

The Potential Soil Erosion Risk (PSER) is then obtained by the product:

$$
P S E R=S E I \cdot E I \cdot S I
$$

and its value is attributed as in Table 7 .

Table 7. Classification to determine the Potential Soil Erosion Risk (PSER).

\begin{tabular}{cll}
\hline Index & Description & Range \\
\hline 1 & None & 0 \\
2 & Low & $0-5$ \\
3 & Middle & $5-11$ \\
4 & High & $>11$ \\
\hline
\end{tabular}

In the second step, the Actual Soil Erosion Risk (ASER) is obtained by integrating the PSER with the Vegetation cover Index of the soil (VI). In particular, the VI is obtained by dividing the land according to the type of vegetation, as in Table 8 .

Table 8. Classification to determine the Vegetation Index (VI).

\begin{tabular}{cll}
\hline Index & Description & Type of Vegetation Cover \\
\hline 1 & fully protected & $\begin{array}{l}\text { woods, forests and permanent pasture } \\
\text { naked or cultivated land5 }\end{array}$ \\
\hline
\end{tabular}

The ASER is obtained starting from the PSER and from the VI, using the matrix shown in Table 9. 
Table 9. Matrix used for the definition of the Actual Soil Erosion Risk index (ASER).

\begin{tabular}{|c|c|c|c|c|c|}
\hline & & \multicolumn{4}{|c|}{ PSER } \\
\hline & & 1 & 2 & 3 & 4 \\
\hline \multirow{2}{*}{$\begin{array}{l}\text { Land cover index } \\
\text { (VI) }\end{array}$} & 1 & 0 & 1 & 1 & 2 \\
\hline & 2 & 0 & 1 & 2 & 3 \\
\hline
\end{tabular}

The result of the application of the CORINE model allows us to define the areas with high risk of erosion (class 3), where control practices are necessary, areas of medium and low risk (class 2 and 1 ), where agricultural practices do not require specific conservation techniques, and finally, areas with zero risk (class 0$)$.

\subsection{Application of the EPM (Gavrilovic)}

The evaluation of material leaving the basin $(G)$ is based on the following relation:

$$
G=W \cdot R
$$

where $W$ is the volume of solid material produced annually by erosion $\left(\mathrm{m}^{3} \mathrm{yr}^{-1}\right)$, obtained by the Equation (7), and $R$ is the reduction factor (Equation (10)):

$$
W=T h \pi \sqrt{z^{n}} F
$$

where:

$T$ = temperature coefficient, defined by Equation (8).

$h=$ average annual rainfalls ( $\mathrm{mm}$ );

$z=$ coefficient of relative erosion, defined by Equation (9);

$n=$ experimental coefficient (generally $=3$ );

$F=$ area of the basin $\left(\mathrm{km}^{2}\right)$.

$$
T=\sqrt{\frac{t^{\prime}}{10}+0.1}
$$

where $t^{\prime}$ is the average annual temperature in the basin $\left({ }^{\circ} \mathrm{C}\right)$.

$$
z=X \cdot Y(\varphi+\sqrt{I})
$$

with:

$X=$ soil coefficient, depending on the vegetational cover;

$Y=$ soil erosivity coefficient, as a function of the prevalent outcropping lithotypes;

$\varphi=$ coefficient that expresses the degree and type of erosive processes;

$I=$ mean slope of the basin, expressed in percentage.

In Tables 10-12 are reported the values of $\mathrm{X}, \mathrm{Y}$ and $\varphi$ to be assigned to the various areas (sub-basins), having homogeneous lithological, vegetational and geomorphological characteristics, in which the main river basin is subdivided (Gavrilovic, [13]).

To define the coefficient $z$ the weighted averages of the values are used of each coefficient relative to the corresponding areas. The reduction factor $R$, according to Zemljic [11], is given by the following expression:

$$
R=\frac{\sqrt{O \cdot D} \cdot\left(L+L_{i}\right)}{(L+10) \cdot F}
$$

where:

$\mathrm{O}=$ basin perimeter $(\mathrm{km})$; 
$D=$ mean elevation, determined by the hypsometric curve $(\mathrm{km})$;

$L=$ lenght of the main stream in the basin $(\mathrm{km})$;

$L_{i}=$ cumulative lenght of the tributaries $(\mathrm{km})$;

$F=$ basin area $\left(\mathrm{km}^{2}\right)$.

Table 10. Values of soil coefficient $X$, based on the type of vegetation cover.

\begin{tabular}{ll}
\hline Types of Vegetation Cover-Coefficient " $\mathbf{X}$ " & Value \\
\hline Mixed forests and dense vegetation patches, forests with glades and undergrowth & $0.05-0.2$ \\
Resinous forests with scarce undergrowth, patches of sparse vegetation & $0.2-0.4$ \\
Forests and degraded vegetation patches, pastures & $0.4-0.6$ \\
Pastures and degraded cultivated lands & $0.6-0.8$ \\
Surfaces without vegetation cover & $0.8-1.0$ \\
\hline
\end{tabular}

Table 11. Values of soil coefficient $Y$, based on the type of rocks-bedrock.

\begin{tabular}{lc}
\hline Erodibility Values-Coefficient " $\mathbf{Y}$ " & Value \\
\hline Hard rocks, resistant to erosion & $0.2-0.6$ \\
Medium-erosion resistant rocks & $0.6-1.0$ \\
Crumbly, stabilized rocks (shales, compact clays, etc.) & $1.0-1.3$ \\
Sediments, moraines, clays and other poorly resistant rocks & $1.3-1.8$ \\
Fine sediments and earths, not resistant to erosion & $1.8-2.0$ \\
\hline
\end{tabular}

Table 12. Values of soil coefficient $\varphi$, based on the visible erosion processes.

\begin{tabular}{ll}
\hline Value of Factor " $\varphi$ ", That Expresses Visible Erosion Processes & Value \\
\hline Weak erosion in the basin & $0.1-0.2$ \\
Erosion in detritus on $20-50 \%$ of the basin & $0.3-0.5$ \\
Erosion in detritus, landslides, karst erosion & $0.6-0.7$ \\
$50-80 \%$ of the basin with landslides and erosion processes & $0.8-0.9$ \\
Basin entirely affected by landslides and erosion processes & 1 \\
\hline
\end{tabular}

\section{Data and Results}

Applying the method proposed by Gavrilovic [13] and using the data from the CORINE Project [27], the volume of material produced by the Rio Huasamayo basin was estimated and the main areas that constitute the source of this material were identified, that is, characterized by greater erosion. In order to better analyze the dynamics of the Rio Huasamayo, its basin has been divided into six sub-basins (Figure 10) renamed as follows-A1, Casa Colorada, Rupasca, Charabozo, San Gregorio and Chicahuada (their main physiographic parameters are reported in Table 13).

The method was applied by generating, in a GIS environment, a layer for each index proposed by the CORINE method [27]. The Soil Erosion Index (SEI) was determined taking into consideration the geological map "Ciudad de Libertador General San Martin, 2366-IV", in scale 1:250,000 and the respective explanatory notes [72], as well as the observations made in the field and from aerial photos by the authors. The classification proposed by the method has been adapted according to the outcropping lithotypes (Table 14).

Due to the lack of meteorological data available and above all the temporal continuity of the measurements, for the determination of the climate erosion index EI (Erosivity Index) the records of rainfalls and temperature acquired by the Tilcara rain gauge were used in its last year of activity, 1990 . The Fournier-Arnoldus index (FI) and the Bagnouls-Gaussen index (BGI) were applied homogeneously for each sub-basin-respectively, a value of 46 was obtained, which corresponds to class 1 (very low) and a value greater than 180 (maximum value for classification), thus assuming a class 4 (very arid). The value of the Erosivity Index (EI), obtained from the product of these two, falls therefore in the 
middle class (2). The Slope Index (SI) was determined using a special function in GIS environment that allows to calculate and classify in pixels the slopes, starting from the ASTER GDEM (30 m resolution).

The ASTER GDEM Validation Team [73] estimated a vertical accuracy of $6.1 \mathrm{~m}$ in flat and open areas and $15.1 \mathrm{~m}$ in mountainous areas, largely covered by forest.

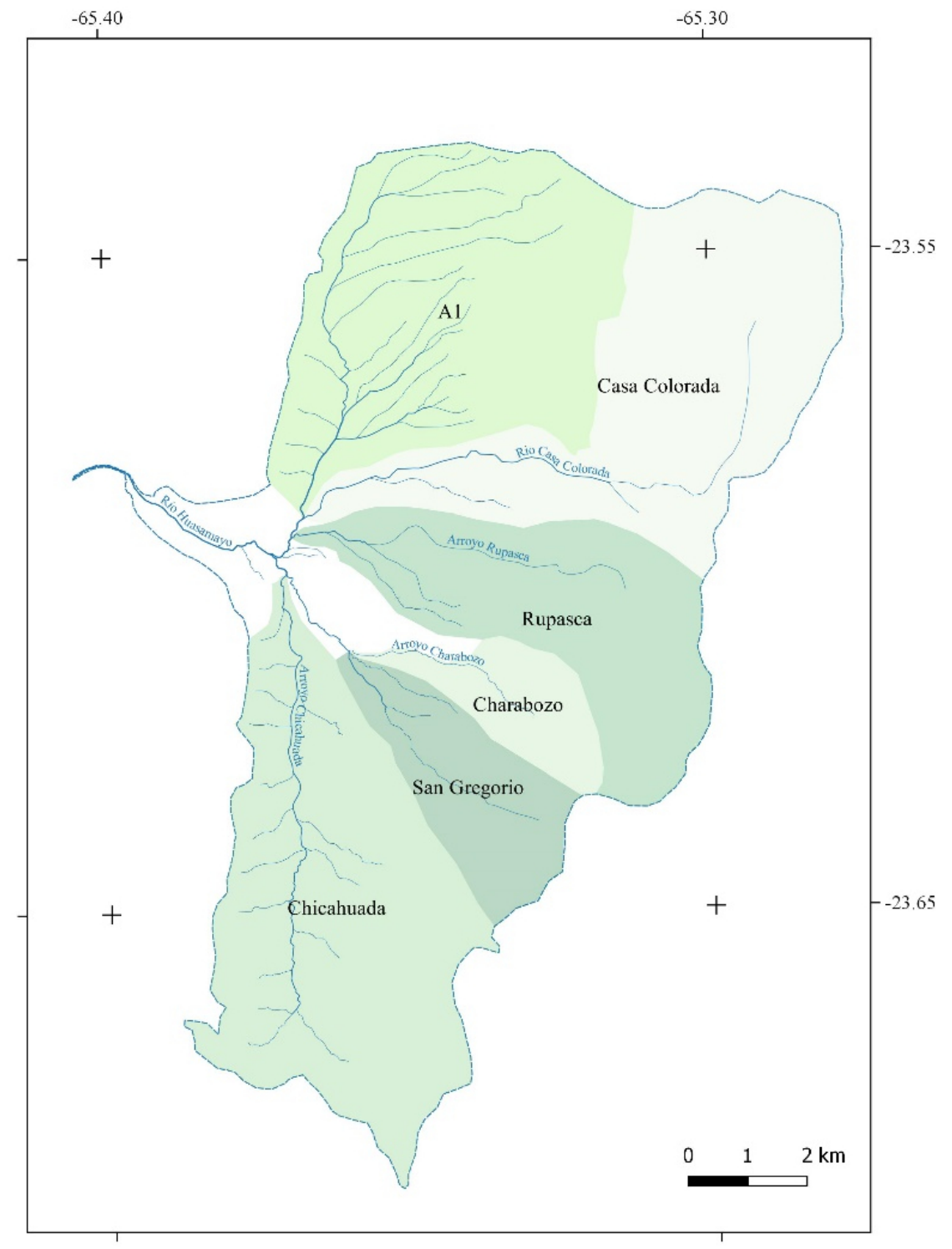

Figure 10. The Rio Huasamayo basin and its main sub-basins.

Table 13. Morphometric parameters of the Rio Huasamayo and its sub-basins.

\begin{tabular}{|c|c|c|c|c|c|c|c|c|}
\hline Basin & $\left(\mathrm{km}^{2}\right)$ & Perimeter & $\begin{array}{c}\text { Max } \\
\text { Elevation } \\
\text { (m a.s.1.) }\end{array}$ & $\begin{array}{c}\text { Min } \\
\text { Elevation } \\
\text { (m a.s.1.) }\end{array}$ & $\begin{array}{l}\text { Mean } \\
\text { Elevation } \\
\text { (m a.s.1.) }\end{array}$ & $\begin{array}{c}\text { Mean } \\
\text { Elevation } \\
\text { (Hypsometric) } \\
\text { (m a.s.l.) }\end{array}$ & $\begin{array}{c}\text { Mean } \\
\text { Slope } \\
(\%)\end{array}$ & $\begin{array}{c}\text { Main } \\
\text { Channel } \\
\text { Lenght } \\
\text { (km) }\end{array}$ \\
\hline Huasamayo & 113.80 & 57.75 & 4740 & 2583 & 3750 & 3458 & 18.99 & 4.09 \\
\hline Chicahuada & 27.70 & 27.38 & 4733 & 2870 & 3732 & 3868 & 20.53 & 8.30 \\
\hline A1 & 26.12 & 21.80 & 4077 & 3130 & 3459 & 3923 & 16.93 & 6.47 \\
\hline C. Colorada & 25.06 & 28.15 & 4536 & 4083 & 4286 & 3518 & 16.24 & 5.80 \\
\hline Rupasca & 16.36 & 20.43 & 4615 & 2969 & 3710 & 3754 & 19.87 & 6.45 \\
\hline S. Gregorio & 8.03 & 13.16 & 3893 & 3331 & 3582 & 3939 & 24.67 & 4.69 \\
\hline Charabozo & 4.83 & 11.33 & 4617 & 3892 & 4196 & 3892 & 27.42 & 3.69 \\
\hline
\end{tabular}


Table 14. Classification of SEI according to the formations outcropping in the study area.

\begin{tabular}{lccc}
\hline Description & $\begin{array}{c}\text { Textural } \\
\text { Class }\end{array}$ & $\begin{array}{c}\text { Depth } \\
\text { Class }\end{array}$ & $\begin{array}{c}\text { Shallow Stoniness } \\
\text { Class }\end{array}$ \\
\hline Alluvial sediments & 3 & 3 & 2 \\
Maimará Formation & 3 & 3 & 2 \\
Jujuy Formation & 3 & 3 & 2 \\
Santa Barbara Subgroup & 2 & 3 & 2 \\
Balbuena Subgroup & 2 & 3 & 2 \\
Pirgua Group & 1 & 1 & 1 \\
Santa Victoria Group & 1 & 2 & 1 \\
Mesón Group & 1 & 2 & 1 \\
Puncoviscana Formation & 1 & 2 & 1 \\
\hline
\end{tabular}

The presence of vegetation in the basin was determined through the use of Landsat satellite images that allowed, again in the GIS context, the calculation of the NDVI index [74]. This index is determined by the ratio between the reflectance values NIR (Near InfraRed) and R (Red), according to the relation:

$$
N D V I=\frac{N I R-R}{N I R+R}
$$

The terms refer to the spectral absorption of chlorophyll in the Red ( $R$, band 3 of the Landsat) and in the near Infrared, where the same reflectance is strongly influenced by the leaf structure (NIR, band 4). By means of this index, it was possible to identify the vegetated areas and then to define a layer for the Vegetation Index with non-vegetated areas and vegetated areas (Figure 11).

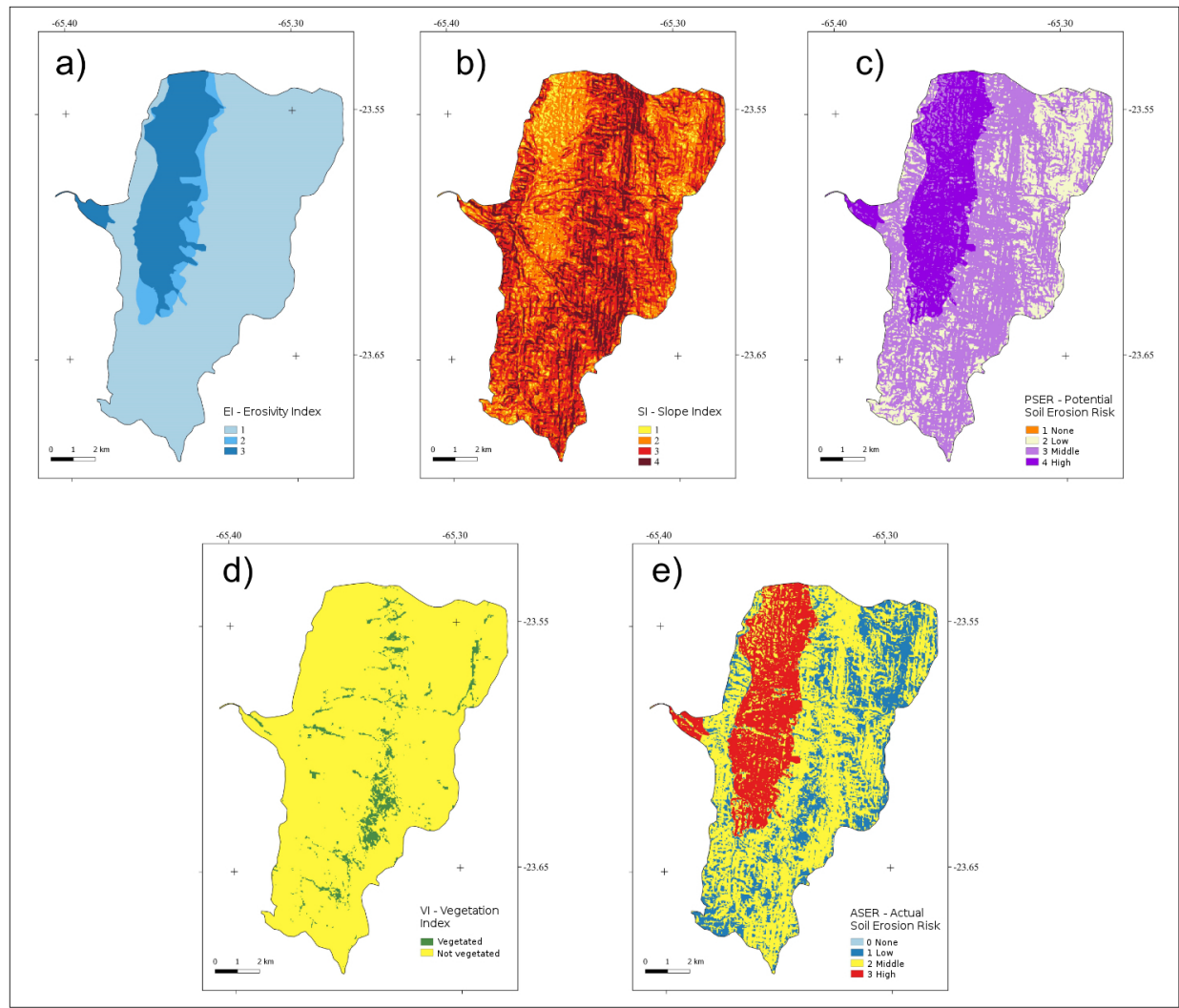

Figure 11. Layouts obtained from the application of the CORINE method: (a) Erosivity Index (EI); (b) Slope Index (SI); (c) Potential Soil Erosion Risk (PSER); (d) Vegetation Index (VI); (e) Actual Soil Erosion Risk (ASER). 
The method proposed by Gavrilovic [13] has allowed estimation of the average production of sediments in the Rio Huasamayo basin and its sub-basins. As a first step, the values of the parameters used by this method (coefficients X, Y and $\varphi$ ) have been attributed, based on Tables 10, 11 and 13.

For other parameters, derived by meteorological data, temperature and rainfall gradients with respect to elevation have been considered. This choice allowed us to assign appropriate values for each basin.

\subsection{Pluviometric Gradient}

For the rainfalls, a regression line has been defined, examining the gauges of Maimará, Vivero Hornillos, Tilcara, Huacalera, Uquia, Humahuaca, Iturbe, Cianzo, Placa de Aparzo and Coctaca. These record a linear trend $\left(R^{2}=0.81\right)$ with a positive precipitation gradient which increases by about $18 \mathrm{~mm}$ every $100 \mathrm{~m}$ (Figure 12), according to the following equation:

$$
y=0.1821 x-313.48
$$

\subsection{Temperature Gradient}

Regarding the temperature values, the gradient proposed by Braun Wilke [31] was used. The temperature decreases of about $0.55^{\circ} \mathrm{C}$ every $100 \mathrm{~m}$, according to the following equation:

$$
y=-0.0045 x+24.343
$$

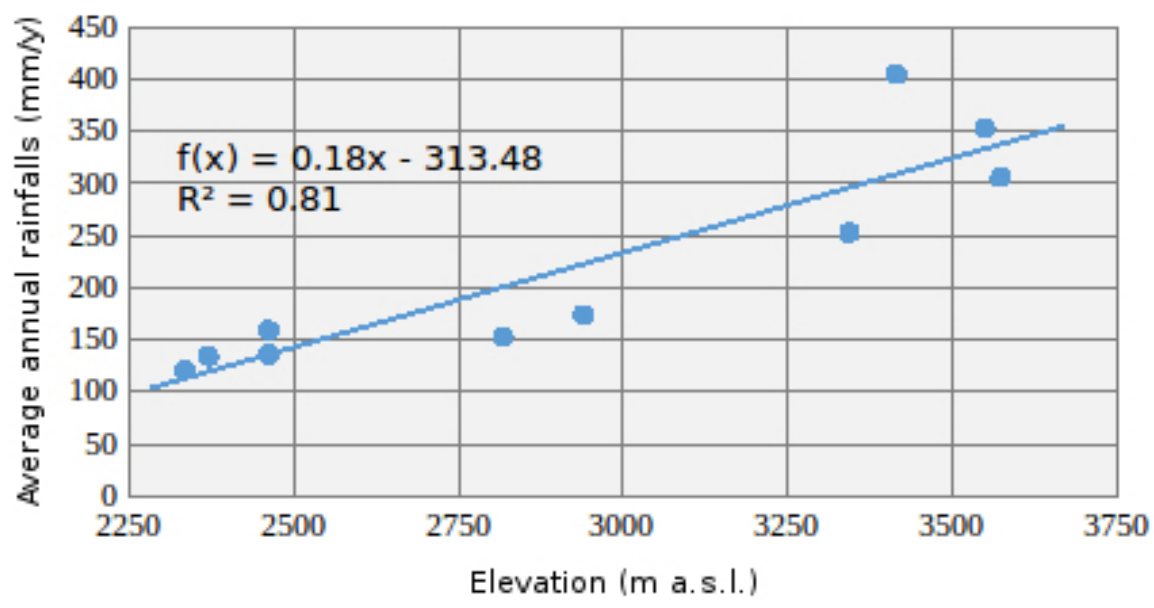

Figure 12. Average annual rainfalls recorded by the rainfall gauges in the Rio Grande valley, ordered according to the elevation in m a.s.l. (Maimarà 2334; Vivero Hornillos 2370; Tilcara 2461; Huacalera 2461; Uquia 2818; Humahuaca 2939; Iturbe 3343; Cianzo 3415; Placa de Aparzo 3550; Coctaca 3573).

\section{Results Obtained From the Application of the Method}

The results obtained are shown in Table 15. The Gavrilovic method estimates an annual production of $56,179 \mathrm{~m}^{3} \mathrm{yr}^{-1}$ for the Rio Huasamayo basin, of which $74.2 \%$ comes from the analyzed sub-basins. In particular, the percentage incidence for each sub-basin is-Chicahuada 10.9\%, A1 37.6\%, Casa Colorada 7.8\%, Rupasca 13.3\%, San Gregorio 3.2\%, and the Charabozo 1.5\%. 
Table 15. Coefficients used for the application of the Gavrilovic Method and results obtained for the Rio Huasamayo basin and its sub-basins.

\begin{tabular}{lccccccccc}
\hline Basin & $\begin{array}{c}\mathbf{X} \\
\text { Coeff. }\end{array}$ & $\begin{array}{c}\mathbf{Y} \\
\text { Coeff. }\end{array}$ & $\begin{array}{c}\boldsymbol{\varphi} \\
\text { Coeff. }\end{array}$ & $\begin{array}{c}\mathbf{z} \\
\text { Coeff. }\end{array}$ & $\begin{array}{c}\mathbf{T} \\
\text { Coeff. }\end{array}$ & $\begin{array}{c}\mathbf{W} \\
\left(\mathbf{m}^{\mathbf{3}} \mathbf{\mathbf { y r } ^ { - 1 }}\right)\end{array}$ & $\begin{array}{c}\mathbf{R} \\
\text { Factor }\end{array}$ & $\begin{array}{c}\mathbf{G}=\boldsymbol{W} \cdot \mathbf{R} \\
\left(\mathbf{m}^{\mathbf{3}} \mathbf{\mathbf { y r }} \mathbf{- 1}\right)\end{array}$ & $\begin{array}{c}\mathbf{G}_{S} \\
\left(\mathbf{m}^{\mathbf{3}} \mathbf{y r}^{-\mathbf{1}} \mathbf{k m}^{-\mathbf{2}} \mathbf{)}\right.\end{array}$ \\
\hline Huasamayo & 0.30 & 1.00 & 0.50 & 1.46 & 0.9 & 185,408 & 0.303 & 56,179 & 493.66 \\
Chicahuada & 0.20 & 1.10 & 0.50 & 1.11 & 0.9 & 36,501 & 0.167 & 6096 & 220.07 \\
A1 & 0.50 & 1.30 & 1.00 & 3.32 & 1.0 & 197,306 & 0.107 & 21,112 & 808.27 \\
C. Colorada & 0.20 & 1.10 & 0.50 & 1.00 & 0.8 & 20,000 & 0.218 & 4360 & 173.98 \\
Rupasca & 0.20 & 1.10 & 0.50 & 1.09 & 0.9 & 20,083 & 0.373 & 7491 & 457.89 \\
S. Gregorio & 0.10 & 1.00 & 0.30 & 0.53 & 1.0 & 3733 & 0.476 & 1777 & 221.30 \\
Charabozo & 0.10 & 1.00 & 0.30 & 0.61 & 0.8 & 2297 & 0.371 & 852 & 176.40 \\
\hline
\end{tabular}

The combined application of the two methods made it possible to identify the sub-basins that provide a greater sediment supply. The areas with a high ASER Index (class 3-Figure 13) are distributed downstream of the Garganta del Diablo, an area in which the Rio Huasamayo basin narrows towards the confluence with the Rio Grande de Jujuy and, above all, in the area with the NS direction between the Sierra de Tilcara (4600 m a.s.l.) and the Cordon de Alfarcito (3200 m a.s.l.).

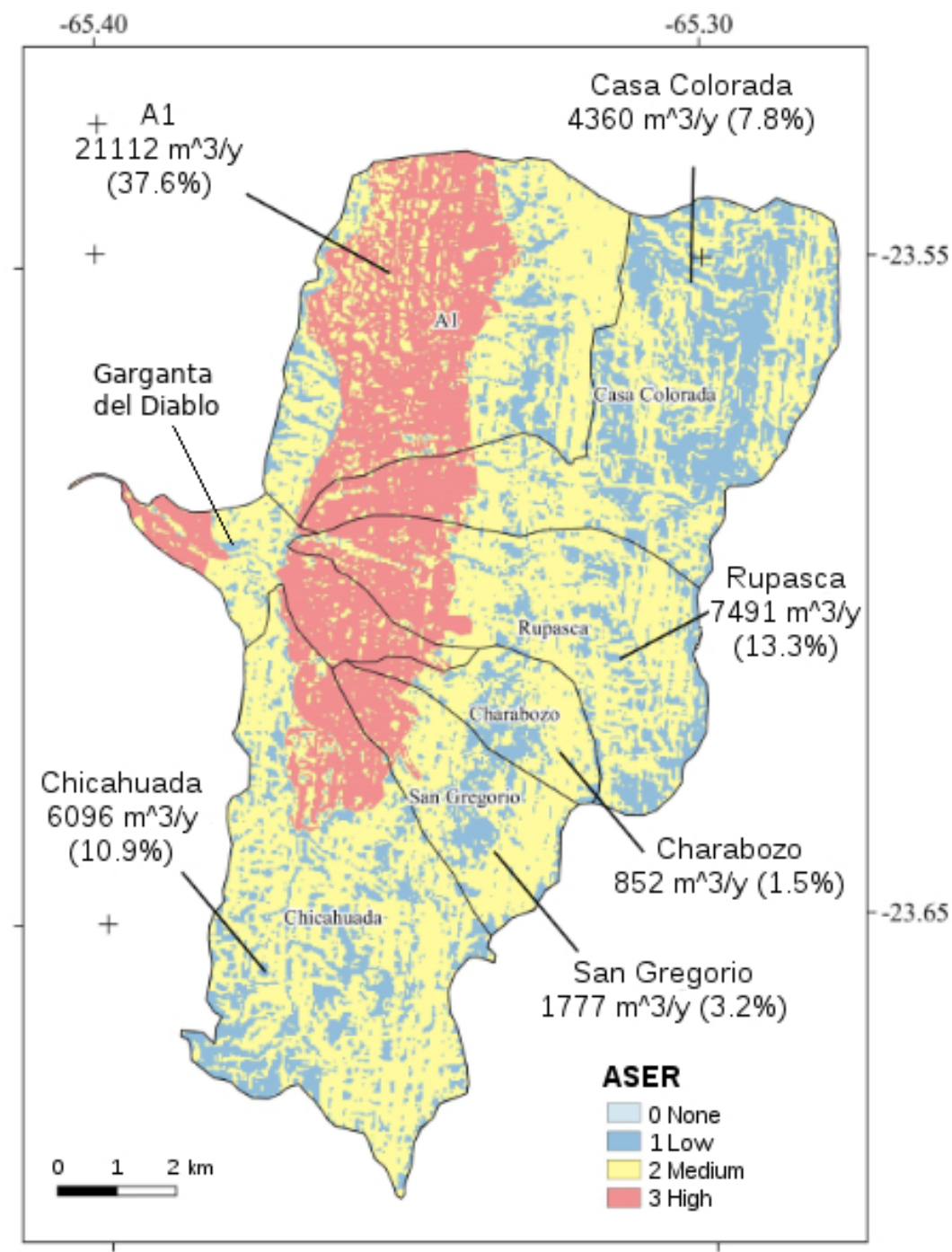

Figure 13. Layout of the Actual Soil Erosion Risk (ASER) Index for the Rio Huasamayo basin, with the respective sub-basins and the values obtained with the Gavrilovic method. 
These two areas have in common the outcrop of Quaternary clastic rocks, consisting of conglomerates with coarse sandy matrix. The lithological characteristics of these sectors played a fundamental role in determining the high ASER index obtained. This observation is reflected in the Gavrilovic method. In fact, the sub-basin A1, which has most of its area in class 3, potentially generates about $37.6 \%\left(21,112 \mathrm{~m}^{3} \mathrm{yr}^{-1}\right)$ of the total sediments exported by the entire Rio Huasamayo basin. The sub-basin $A 1$ has also the maximum value of $G_{s}$ (specific $G=$ volume of solid material produced annually by erosion per $\mathrm{km}^{2}$ ).

\section{Discussion}

\subsection{Causes of the Hydrogeological Risk in Tilcara}

The main problem affecting the village of Tilcara is its position, because the village grew on the alluvial fan at a lower level than the Rio Huasamayo riverbed, in natural aggradation.

To eliminate the hydrological risk that characterizes the town of Tilcara, Marcato et al. [60] proposed to divert the Rio Huasamayo from the section immediately downstream of the Garganta del Diablo, up to the left bank of the Rio Grande, close to Maimará (a village south of Tilcara). This operation would require excavation in the Pliocene sediments on the left bank of the Rio Huasamayo, to create an artificial channel that would divert it and the construction of an earth-dam to force it to follow the new path, abandoning its natural riverbed.

We think that the proposal of this kind of work could safeguard the city of Tilcara, not reducing, however, the hydrological risk but transferring it further downstream at the expense of the village of Maimará.

We retain that the main problem is the high watershed sediments supply that causes the aggradation of river streams and increases the hydrogeological hazard and risk.

The result obtained combining the CORINE method and the Gavrilovic method allowed to identify the sectors in which it is possible to carry out targeted interventions, reducing the erosion and the debris removal from the slopes of the Rio Huasamayo basin, so avoiding the triggering of debris flows and the aggradation of the riverbed.

\subsection{Possible Solutions}

Local-scale works of hydrological risk-reduction should be coupled with basin-scale works (i.e., design solutions that affect not only the riverbed but also the slopes of the entire basin) to reduce sediment supply. These basin-scale works would make easier all maintenance operations that can be planned and carried out downstream. In the absence of this, levees should be periodically over-elevated and checked dams should be maintained more frequently.

It is therefore considered appropriate to act at the root of the problem, creating erosion control works, both active (e.g., slope coverings with wire mesh, with geogrids or geomats) and passive type, such as the construction of weirs along the minor fluvial channels of the basin, which would have the dual purpose of decreasing the average slope of the channels themselves and retaining the solid transport, working, that is, both as consolidation weirs and as holding weirs (hard structures).

An option could be the construction of soft-medium structures, that is, flexible ring net barriers [75,76], which adapt very well to fluvial cross sections and allow solid transport to be retained without hindering water flows. Furthermore, if compared to similar concrete works, they are easier to make at a lower cost. In addition, this type of intervention would surely have a lower visual impact compared to a possible single dam near the Garganta del Diablo, which is today an important tourist destination.

The choice of the type of defense work, the location and the dimensions require careful planning by experts, who must also take into account maintenance operations following any impact. In the case of flexible ring net barriers, in addition to removing the retained material, the ropes, anchors and 
brakes of the net must be overhauled to prevent a subsequent event from overriding the obstacle or even completely destroying the structure.

Finally, the need to install a network of rain gauges in the Rio Huasamayo basin is underlined, capable of recording the rainfalls and communicating data instantly with the GPRS system, to the local authorities.

\section{Conclusions}

The hydrogeological hazard and risk conditions affecting the Tilcara area (northwestern Argentina) have been addressed by identifying the underlying causes. The enormous sedimentary supply from the slopes of the Rio Huasamayo is undoubtedly the main cause of the process of aggradation of the Rio Huasamayo riverbed at the apex of the alluvial fan built at the mouth of the Rio Grande valley (Quebrada de Humahuaca). This process of aggradation of the riverbed and therefore of potential hydrogeological hazard, combined with the presence of a built-up area (Tilcara) in the area of the fan (which leads to a high territorial vulnerability), involves obvious conditions of hydrogeological risk. Therefore, the problem consists of:

- identifying the areas of greatest debris production from the slopes of the Rio Huasamayo basin;

- quantifying the sediment supply to the Rio Huasamayo;

- proposing solutions for the mitigation of hydrogeological risk.

The problem was not easy to solve, especially due to the lack of hydrometeorological data in the area of Tilcara (and, more generally, in the whole Quebrada de Humahuaca valley) which does not allow the application of the most used methods in the literature (i.e., USLE, RUSLE), which are certainly more rigorous for assessing the erodibility of slopes and sediment supply.

The novelty of the proposed approach is to use the combination of two methods (Gavrilovic and CORINE) which, on the one hand, allow the identification of the areas of greatest detrital production (CORINE) and, on the other hand, quantify the sediment supply (Gavrilovic).

In particular, the Gavrilovic method-originally used only for Mediterranean area basins-has been extensively tested in other contexts and has demonstrated its application validity even in sub-arid climate areas, such as the examined one. Some precautions have been taken; in particular, the temperature gradient of Braun Wilke was used and a precipitation gradient with respect to the altitude was estimated. These choices have allowed appropriate attribution and more reliable values for each sub-basin of the Rio Huasamayo.

In the application of the CORINE method, the problem related to meteorological data was presented again. In particular, the Fournier-Arnoldus index and the Begnouls-Gaussen index, defined to obtain the climatic Erodibility Index (EI), were determined considering the last year of recording (1990) of the meteorological station of Tilcara. This represents a limitation of the application of the method, which however cannot be avoided due to the lack of more recent data; however, these are the only data available and in any case are able to provide reliable information on the Quebrada meteorological conditions, necessary for the application of the CORINE method.

This approach has led to results that can have a good degree of reliability, in order to estimate which areas of the Rio Huasamayo basin are affected by great erosion processes and the total amount of sediment yield upstream of the Tilcara village.

We suggest that local scale works of hydrological risk-reduction, as proposed by Marcato et al. [60], should be coupled with basin-scale works to reduce sediment supply. This approach would reduce the hydrogeological hazard and make easier all maintenance operations for the works realized in the downstream reach. In the absence of these interventions, levees should be periodically over-elevated and checked dams should be maintained more frequently. 
The obtained results allow the identification of watershed areas where interventions for the solid transport control would be most effective. The estimation of the sediment yield, obtained with the Gavrilovic method, can be used for a first analysis on the frequency and on the dimensions of the works.

These appear irrepressible, also considering the high tourist vocation of the area, which since 2003 has become a UNESCO World Heritage Site.

Author Contributions: Methodology, E.P. and C.C.; Field data collection, E.P. and F.R.R.; GIS data analysis E.P., A.F. and P.D.R.; Project administration and funding acquisition C.C.; Supervision C.C. and F.R.R.; All authors wrote the paper.

Funding: This research was funded by Università degli Studi di Perugia in the framework of the Cultural Agreement between Università degli Studi di Perugia-Italy (Scientific manager: Corrado Cencetti) and Universidad Nacional de Salta-Argentina (Scientific manager: Felipe Raphael Rivelli).

Acknowledgments: The authors would like to thank the three anonymous reviewers for their comments and suggestions, thus contributing significantly to improving the paper.

Conflicts of Interest: The authors declare no conflict of interest.

\section{Abbreviations}

The following abbreviations are used in this manuscript:

PSER Potential Soil Erosion Risk

ASER Actual Soil Erosion Risk

EI Erosivity Index

EPM Erosion Potential Method

\section{References}

1. Brambilla, D.; Longoni, L.; Papini, M.; Giorgetti, E.; Radice, A. On analysis of sediment sources toward proper characterization of hydro-geological hazard for mountain environments. Int. J. Saf. Secur. Eng. 2011, 1, 423-437. [CrossRef]

2. Brambilla, D.; Longoni, L.; Mazza, F.; Papini, M. Sediment yield from mountain slopes: A GIS based automation of the classic Gavrilovic method. River Basin Manag. VI 2011, 146, 301.

3. Lane, S.N.; Tayefi, V.; Reid, S.C.; Yu, D.; Hardy, R.J. Interactions between sediment delivery, channel change, climate change and flood risk in a temperate upland environment. Earth Surf. Process. Landf. 2007, 32, 429-446. [CrossRef]

4. Reid, S.C.; Lane, S.N.; Berney, J.M.; Holden, J. The timing and magnitude of coarse sediment transport events within an upland, temperate gravel-bed river. Geomorphology 2007, 83, 152-182. [CrossRef]

5. Sear, D.A.; Newson, M.D.; Brookes, A. Sediment-related river maintenance: The role of fluvial geomorphology. Earth Surf. Process. Landf. 1995, 20, 629-647. [CrossRef]

6. Di Silvio, G. Floods and sediment dynamics in mountain rivers. In Coping with Floods; Rossi, G., Harmancioğlu, N., Yevjevich, V., Eds.; Springer: Dordrecht, The Netherlands, 1994; pp. 375-392. [CrossRef]

7. Klaassen, G.; Barneveld, H.; Peviani, M.; Di Silvio, G. FRIMAR: Flooding Risks in Mountain Areas; Final Report; Delft Hydraulics: Delft, The Netherland, 1997.

8. Ivanov, V.I. Hydro-Geological Process Chain for Building a Flood Scenario. Master's Thesis, Politecnico di Milano, Piazza Leonardo da Vinci, Milano, Italy, 1993.

9. Rivelli, F.R.; Zelarayan, A.L. Relieve, Morfogenesis, Ordenamiento Territorial Y Riesgos, El Caso De Tilcara (Jujuy, Republica Argentina); Actas Cientificas CIG, $77^{\circ}$ Semana de la Geografia; 2016; pp. 207-224. Available online: http:/ / www.gaea.org.ar / ACTAS/RIVELLI_Felipe.pdf (accessed on 13 November 2019).

10. Gavrilovic, S. Inzenjering o Bujicnim Tokovima i Eroziji. časopis Izgradnja-Specijalnp izdanje 1972. (In Bosne)

11. Zemljic, M. Calcul du débit solide-Evaluation de la végétation comme un des facteurs antiérosif. In Proceedings of the International Symposium Interpraevent; Interpraevent: Villach, Austria, 1971; Volume 2, pp. 359-371. 
12. Djorovic, M.; Gravilovic, S. Quantitative Classification of Torrent Waterways; Institute for Forestry and Wood Industry: Belgrade, Serbia, 1974.

13. Gavrilović, Z. The use of en empirical method (Erosion Potential Method) for calculationg sediment production and trasportation in unstudied or torrential streams. In Proceedings of the International Conference on River Regime, Wallingford, UK, 18-20 May 1988; White, W.R., Ed.; Hydraulics Research Ltd.: Chichester, UK; New York, NY, USA, 1988; pp. 411-422.

14. Charizopoulos, N.; Mourtzis, P.; Psilovikos, T.; Psilovikos, A.; Karamoutsou, L. Morphometric analysis of the drainage network of Samos Island (northern Aegean Sea): Insights into tectonic control and flood hazards. C. R. Geosci. 2019. [CrossRef]

15. Dalaris, M.; Psilovikos, A.; Sapountzis, M.; Mourtzis, P. Water erosion assessment in skiathos island using the gavrilovic method. Fresenius Environ. Bull. 2013, 22, 2943-2952.

16. Milanesi, L.; Pilotti, M.; Clerici, A.; Gavrilović, Z. Application of an improved version of the erosion potential method in alpine areas. Ital. J. Eng. Geol. Environ. 2015, 1, 17-30.

17. Dragičević, N.; Whyatt, D.; Davies, G.; Karleuša, B.; Ožanić, N. Erosion model sensitivity to land cover inputs: Case study of the Dubračina catchment, Croatia. In Proceedings of the GIS Research UK 22nd Annual Conference GISRUK, Glasgow, UK, 16-18 April 2014; pp. 340-348.

18. Dragičević, N.; Karleuša, B.; Ožanić, N. Erosion potential method (Gavrilović method) sensitivity analysis. Soil Water Res. 2017, 12, 51-59. [CrossRef]

19. Abedian, S.; Salman Mahiny, A.; Karbakhsh Ravori, H. Estimating of erosion and sediment yield of Gorganrud basin using erosin potential method. Nat. Environ. Chang. 2017, 3, 19-32.

20. Kostadinov, S.; Braunović, S.; Dragićević, S.; Zlatić, M.; Dragović, N.; Rakonjac, N. Effects of Erosion Control Works: Case Study—Grdelica Gorge, the South Morava River (Serbia). Water 2018, 10, 1094. [CrossRef]

21. Markhi, A.; Laftouhi, N.; Grusson, Y.; Soulaimani, A. Assessment of potential soil erosion and sediment yield in the semi-arid Nfis basin (High Atlas, Morocco) using the SWAT model. Acta Geophys. 2019, 67, $263-272$. [CrossRef]

22. Spalevic, V.; Tazioli, A.; Djekovic, V.; Andjelkovic, A.; Djurovic, N. Assessment of soil erosion in the Lipnica watershed, Polimlje, Montenegro. In Proceedings of the Fifth International Scientific Agricultural Symposium Agrosym 2015, Jahorina, Bosnia and Herzegovina, 23-26 October 2014; pp. 723-729.

23. Bagherzadeh, A.; Daneshvar, M.R.M. Sediment yield assessment by EPM and PSIAC models using GIS data in semi-arid region. Front. Earth Sci. 2011, 5, 207. [CrossRef]

24. Bagherzadeh, A.; Mansouri Daneshvar, M.R. Estimating and mapping sediment production at Kardeh watershed by using GIS. In Proceedings of the 1st International Applied Geological Congress, Mashad Branch, Iran, 26-28 April 2010; pp. 1440-1446. Available online: http:/ / conference.khuisf.ac.ir/DorsaPax/ userfiles/file/pazhohesh/zamin\%20mashad/258.pdf (accessed on 13 November 2019).

25. Dragičević, N.; Karleuša, B.; Ožanić, N. A review of the Gavrilović method (erosion potential method) application. Građevinar časopis Hrvat. Saveza Građevinskih Inženjera 2016, 68, 715.

26. Darvishan, A.K.; Derikvandi, M.; Aliramaee, R.; Khorsand, M.; Spalevic, V.; Gholami, L.; Vujacic, D. Efficiency of IntErO Model to Predict Soil Erosion Intensity and Sediment Yield in Khamsan Representative Watershed (West of Iran). AGROFOR 2016, 3, 22-31. [CrossRef]

27. Commission of European Community. Corine Soil Erosion Risk and Important Land Resources in The Southern Regions of the European Community an Assessment to Evaluate and Map the Distribution of Land Quality and Soil Erosion Risk; EU Pubblications, Office for Official Publications of the European Communities: Brussels, Belgium, 1992.

28. Cencetti, C. River Dynamics in the Cordillera Orientale of the Andes (northwestern Argentina). Ital. J. Eng. Geol. Environ. 2008, 1, 151-184.

29. Chayle, W.; Aguero, P. Características de Remoción en Masa en la Cuenca del Rio Grande, Quebrada de Humahuaca Jujuy; Revista del Instituto de Geologia y Mineria, Universidad Nacional de Jujuy: San Salvador de Jujuy, Argentina, 1987; Volume 7, pp. 24-31.

30. Bianchi, A.; Yanez, C. Las Precipitaciones en el Noroeste Argentino (Segunda Edición); Estación Experimental Agropecuaria Salta del Instituto Nacional de Tecnología Agropecuaria: Salta, Argentina, 1992. 
31. Braun Wilke, R.H. Carta de Aptitud Ambiental de la Provincia de Jujuy; Departamento de Suelos y Ecología, Facultad de Ciencias Agrarias, Universidad Nacional de Jujuy: Jujuy, Argentina, 2001.

32. SEGEMAR. Estudio Integrado de la Quebrada de Humahuaca; Technical Report; Servicio Geológico Minero Argentino: Buenos Aires, Argentina, 1998.

33. Turner, J. Estratigrafia de la Sierra de Santa Victoria y adiacencia. Acad. Nac. Cs. Cord. Bol. 1960, 41, $163-196$.

34. Aceñolaza, F. Sobre la presencia de Oldhamia sp. En la Formación Puncoviscana de Cuesta Muñano, Provincia de Salta, República Argentina. Rev. De La Asoc. Geológica Argent. 1973, 28, 56-60.

35. Halpern, M.; Latorre, C. Estudio geocronológico inicial de rocas del noroeste de la República Argentina. Rev. De La Asoc. Geológica Argent. 1973, 28, 195-205.

36. Salfity, J.; Omarini, R.; Baldis, B.; Gutierrez, W. Consideraciones sobre la evolución geotectónica del Precámbrico y Paleozoico Inferior del Norte de Argentina. In Proceedings of the Actas Segundo Congreso Iberoamericano de Geologia Económica, Buenos Aires, Argentina, 15-19 December 1975; Volume 4, pp. 341-362.

37. Harrington, H.; Leanza, A. Ordovician Trilobites of Argentina; Special Publication; Department of Geology, University of Kansas: Lawrence, KS, USA, 1957; Volume 1.

38. Zanettini, J. Geología de la comarca de Abra Pampa y Tres Cruces (provincia de Jujuy). Rev. De La Asoc. Geológica Argent. 1973, 28, 331-340.

39. Amengual, R.; Zanettini, J. Geología de la quebrada de Humahuaca entre Uquía y Purmamarca (Provincia de Jujuy). Rev. De La Asoc. Geológica Argent. 1974, 29, 30-40.

40. Spencer, F. The geology of the Aguilar lead-zinc mine. Argentina. Econ. Geol. 1950, 45, 405-433. [CrossRef]

41. Brodtkorb, M.; Lanfranco, J.; Sureda, R. Asociaciones minerales y litología de1 yacimiento Aguilar, Prov. de Jujuy, República Argentina. Rev. De La Asoc. Geológica Argent. 1978, 33, $277-298$.

42. Sureda, R.; Martin, J. Mina El Aguilar, Provincia de Jujuy, Rep. Argentina. Un depósito Sedex ordovícico con metamorfismo de contacto sobreimpuesto en la provincia metalogénica quiaqueña. In Contr. Conoc. Mineralogía y Geología Económica Rep.; AAGE: La Plata, Argentina, 1990; pp. 78-92.

43. Sureda, R.J.; Martin, J.L. El Aguilar Mine: An Ordovician Sediment-Hosted Stratiform Lead-Zinc Deposit in the Central Andes. In Stratabound Ore Deposits in the Andes; Fontboté, L., Amstutz, G.C., Cardozo, M., Cedillo, E., Frutos, J., Eds.; Springer: Berlin/Heidelberg, Germany, 1990; pp. 161-174._10. [CrossRef]

44. Gemmell, J.B.; Zantop, H.; Meinert, L.D. Genesis of the Aguilar zinc-lead-silver deposit, Argentina; contact metasomatic vs. sedimentary exhalative. Econ. Geol. 1992, 87, 2085-2112. [CrossRef]

45. Martin, J.L.; Flores, F.J.; Sureda, R.J. Investigacion geoquimica en un yacimiento'sedex'del Ordovicico Inferior: Mina El Aguilar, Jujuy, Argentina. Andean Geol. 1994, 21, 71-90.

46. Turner, J. Faunas graptoliticas de América del sur. Rev. De La Asoc. Geológica Argent. 1959, 15, 1-180.

47. Brackebusch, L. Mapa Geológico del Interior de la República Argentina, Escala 1:1.000.000; Actas de la Academia Nacional de Ciencias, Academia Nacional de Ciencias de la Repubblica Argentina: Cordoba, Argentina, 1891.

48. Vilela, R. Acerca del hallazgo del horizonte calcáreo dolomitico en la Puna Salto-Jujeña y su significado geológico. Rev. De La Asoc. Geológica Argent. 1951, 6, 101-107.

49. Reyes, F.; Salfity, J. Consideraciones sobre la estratigrafia de Cretácico (Subgrupo Pirgua) del noroeste argentino. In Proceedings of the $5^{\circ}$ Congreso Geológico Argentino, Villa Carlos Paz, Argentina, 22-28 October 1972; 1973; Volume 3, pp. 355-385.

50. Moreno, J.A. Estratigrafía y Paleogeografía del Cretácico Superior en la Cuenca del Noroeste Argentino, con Especial Mención de los Subgrupos Balbuena y Santa Bárbara; Revista de la Asociacion Geologica Argentina: Buenos Aires, Argentina, 1970, pp. 9-44.

51. Grier, M. The Influence of the Cretaceous Salta Rift Basin on the Development of Andean Structural Geometries NW Argentina-Andes. Ph.D. Thesis, Cornell University, Ithaca, NY, USA, 1990; Unpublished.

52. Fernández, J.; Bondesio, P.; Pascual, R. Restos de Lepidosiren paradoxa (Osteichthyes, Dipnoi) de la Formación Lumbrera (Eógeno, Eoceno?) de Jujuy. Ameghiniana 2013, 10, 152-172.

53. Coira, B.L. Descripción Geológica de la Hoja 3C Abra Pampa, Provincia de Jujuy; Number 170 in Boletín (Argentina. Servicio Geológico Nacional); República Argentina, Ministerio de Industria y Minería, Subsecretaría de Minería, Servicio Nacional Minero Geológico: Buenos Aires, Argentina, 1979. 
54. Bond, M.; López, G. Los mamiferos de la Formación Casa Grande (Eoceno) de la provincia de Jujuy. Argentina. Ameghiniana 2014, 32, 301-309.

55. Pascual, R.; Vucetich, M.; Fernández, J. Los primeros mamiferos (Notangulata, Hericoskornidae) de la F. Mealla (Gr. Salta, Subgr. Santa Bárbara). Su implementación filogenética, taxonómica y cronológica. Ameghiniana 1978, 15, 366-390.

56. Salfity, J.; Gorwtovich, S.; Moya, M. Las fases diastróficas en Los Andes del Norte Argentino. In Proceedings of the Simposio Internacional de "Tectónica Centro-Andina y Relaciones con Recursos Naturales"; Comisión Nacional de Estudios Geofisicos, Academia Nacional de Ciencias: La Paz, Bolivia, 1993.

57. Castellanos, A. El Uquiense, Sedimentos Neógenos de Uquía (Senador Perez) en la Provincia de Jujuy (Argentina); Technical Report 36; Facultad de Ciencias Matemáticas Físicas Químicas y Naturales de la Universidad Nacional del Litoral: Rosario, Argentina, 1950.

58. Chayle, W.; Wayne, W. Impact of Erosion, Mass Wasting, and Sedimentation on Human Activities in the Río Grande Basin, Jujuy Province, Argentina. Environ. Eng. Geosci. 1995, I, 403-416. [CrossRef]

59. Sancho, C.; Peña, J.L.; Rivelli, F.; Rhodes, E.; Muñoz, A. Geomorphological evolution of the Tilcara alluvial fan (Jujuy Province, NW Argentina): Tectonic implications and palaeoenvironmental considerations. J. South Am. Earth Sci. 2008, 26, 68-77. [CrossRef]

60. Marcato, G.; Bossi, G.; Rivelli, F.; Borgatti, L. Debris flood hazard documentation and mitigation on the Tilcara alluvial fan (Quebrada de Humahuaca, Jujuy province, North-West Argentina). Nat. Hazards Earth Syst. Sci. 2012, 12, 1873-1882. [CrossRef]

61. Flacke, W.; Auerswald, K.; Neufang, L. Combining a modified Universal Soil Loss Equation with a digital terrain model for computing high resolution maps of soil loss resulting from rain wash. Catena 1990, 17, 383-397. [CrossRef]

62. Warren, S.D.; Diersing, V.E.; Thompson, P.J.; Goran, W.D. An erosion-based land classification system for military installations. Environ. Manag. 1989, 13, 251-257. [CrossRef]

63. Huang, S.L.; Ferng, J.J. Applied land classification for surface water quality management: I. Watershed classification. J. Environ. Manag. 1990, 31, 107-126. [CrossRef]

64. Mitasova, H.; Hofierka, J.; Zlocha, M.; Iverson, L.R. Modelling topographic potential for erosion and deposition using GIS. Int. J. Geogr. Inf. Syst. 1996, 10, 629-641. [CrossRef]

65. Renard, K.; Yoder, D.; Lightle, D.; Dabney, S. Universal soil loss equation and revised universal soil loss equation. Handb. Eros. Model. 2011, 8, 135-167.

66. Chalise, D.; Kumar, L.; Shriwastav, C.P.; Lamichhane, S. Spatial assessment of soil erosion in a hilly watershed of Western Nepal. Environ. Earth Sci. 2018, 77, 685. [CrossRef]

67. Mitas, L.; Mitasova, H. Distributed soil erosion simulation for effective erosion prevention. Water Resour. Res. 1998, 34, 505-516. [CrossRef]

68. USDA-Soil Science Division Staff. Soil Survey Manual; Number 18 in USDA Handbook; Government Printing Office: Washington, DC, USA, 2017.

69. Arnoldus, H.M.J. An Approximation of the Rainfall Factor in the Universal Soil Loss Equation. In Assessment of Erosion; De Boodt, M., Gabriels, D., Eds.; John Wiley and Sons: New York, NY, USA, 1980; Chapter PART 3, pp. 127-132.

70. Gaussen, H. Théories et classification des climats et microclimats. In Proceedings of the 8me Congrès International de Botanique, Paris, France, 2-14 July 1954; Volume 7, pp. 125-130.

71. Gaussen, H. Expression des milieux par des formules écologiques. Leur représentation cartographique. Ann. Biol. 1955, 31, 257-269.

72. González, M.A.; Tchilinguirian, P.; Pereyra, F.X.; Ramallo, E.; González, O.E. Hoja Geológica 2366-IV Ciudad de Libertador General San Martín; Bolletin; SEGEMAR: Bueno Aires, Argentina, 2004; Volume 274, 109p.

73. Tachikawa, T.; Kaku, M.; Iwasaki, A.; Gesch, D.B.; Oimoen, M.J.; Zhang, Z.; Danielson, J.J.; Krieger, T.; Curtis, B.; Haase, J.; et al. ASTER Global Digital Elevation Model Version 2-Summary of Validation Results. Report, 2011. Available online: https://ssl.jspacesystems.or.jp/library/archives/ersdac/GDEM/ ver2Validation/Summary_GDEM2_validation_report_final.pdf (accessed on 13 November 2019).

74. Rouse, J.W.; Haas, R.H.; Deering, D.W.; Schell, J.A.; Harlan, J.C. Monitoring the Vernal Advancement and Retrogradation (Green Wave Effect) of Natural Vegetation; Final Report; NASA/GSFC: Greenbelt, MD, USA, 1974. 
75. Wendeler, C.; McArdell, B.W.; Volkwein, A.; Denk, M.; Gröner, E. Debris Flow Mitigation with Flexible Ring Net Barriers-Field Tests and Case Studies. In Monitoring, Simulation, Prevention and Remediation of Dense and Debris Flows II; Wrachien, D.D., Brebbia, C., Lenzi, M., Eds.; WIT Transactions on Engineering Sciences; WIT Press: Southampton, UK, 2008; Volume 60, pp. 23-31.

76. Wendeler, C.; Gröner, E.; Matthesius, J. Protection against debris flows using flexible ring net barriers in the Teufelskadrich, Germany/Murgangschutz Teufelskadrich mit flexiblen Ringnetzbarrieren. Geomech. Tunn. 2012, 5, 389-396. [CrossRef]

(c) 2019 by the authors. Licensee MDPI, Basel, Switzerland. This article is an open access article distributed under the terms and conditions of the Creative Commons Attribution (CC BY) license (http://creativecommons.org/licenses/by/4.0/). 